\title{
The Role of Aerosols in Convective Processes during the Midsummer Drought in the Caribbean
}

\author{
Nathan Hosannah, ${ }^{1}$ Hamed Parsiani, ${ }^{1}$ and Jorge E. González ${ }^{2}$ \\ ${ }^{1}$ The Electrical and Computer Engineering Department, University of Puerto Rico at Mayagüez, Mayagüez, PR, USA \\ ${ }^{2}$ The Mechanical Engineering Department, The City College of New York, New York, NY, USA \\ Correspondence should be addressed to Nathan Hosannah; nhosannah@gmail.com
}

Received 6 April 2015; Revised 18 June 2015; Accepted 18 June 2015

Academic Editor: Eduardo García-Ortega

Copyright (c) 2015 Nathan Hosannah et al. This is an open access article distributed under the Creative Commons Attribution License, which permits unrestricted use, distribution, and reproduction in any medium, provided the original work is properly cited.

\begin{abstract}
Saharan dust (SD) heavily impacts convective precipitation in the Caribbean. To better understand the role of SD in precipitation development during the midsummer drought (MSD), an observational campaign, centered at the city of Mayagüez, Puerto Rico $(18.21 \mathrm{~N}, 67.13 \mathrm{~W})$, between 3 June and 15 July 2014, was conducted in order to select a range of atmospheric conditions to be simulated using the Regional Atmospheric Modeling System (RAMS) cloud resolving model under "no SD" and "SD" conditions. The events included one dry day with moderate-heavy SD, one localized moderate rainfall event with moderate SD, one islandwide light precipitation event with heavy SD, and one island-wide heavy precipitation event with light-moderate SD. Model results show that (1) precipitation results are improved when compared with observation with the presence of SD, (2) precipitation, cloud fraction, dew point temperatures, and humidity are significantly reduced under SD conditions, (3) precipitation can occur when SD is removed for a dry day, (4) there is evidence of rain being delayed due to the presence of SD without rainfall intensity or accumulation increases, (5) liquid mixing ratio increases of up to $1.4 \mathrm{~g} \mathrm{~kg}^{-1}$ occur in the absence of SD, and (6) vertical wind increases of up to $0.8 \mathrm{~m} \mathrm{~s}^{-1}$ occur in the absence of SD.
\end{abstract}

\section{Introduction}

Investigation of precipitation processes in warm environments such as the Caribbean is of paramount importance, as these regions are susceptible to intense precipitation events that can lead to extreme flooding [1]. Rainfall in the region is modulated by sea surface temperature (SST), the North Atlantic High Pressure (NAHP), which guides the trade winds and modifies vertical wind shear (VWS), and an intensely dry and dust laden Saharan Air Layer (SAL) that travels from the African Sahara across the Atlantic Ocean towards the Caribbean [2].

Characterized as bimodal, Caribbean rainfall peaks in the early and late rainfall seasons (ERS and LRS) which span from March to May and August to October, respectively, and has reduced totals during the midsummer drought (MSD) which takes place between June and July [3]. The peak of the MSD depends upon longitudinal location, occurring later at western sites than at eastern sites [4]. Puerto Rico, which is located near the longitudinal center of the Caribbean basin, experiences a peak in the MSD between late June and early July.

Since SSTs in the Caribbean are within the favorable temperature threshold for precipitation enhancement during the MSD, $26.5^{\circ} \mathrm{C}$ to $29.5^{\circ} \mathrm{C}$, as specified by Folkins and Braun [5], the reduction in precipitation is in part attributed to the presence of the SAL which may extend from 1.5 to $5.5 \mathrm{~km}$ in the vertical, as measured by in situ flight campaigns across the Caribbean [6]. The iron-rich Saharan dust (SD) particles in the SAL inhibit convective cloud development and enhance the trade wind inversion [7].

Precipitation climatologies created with global historical climate network (GHCN) station data and aerosol volume concentrations measured from the Aerosol Robotic Network (AERONET) at two sites on the main island of Puerto Rico including San Juan (18.45 N, 66.07 W) and Mayagüez $(18.21 \mathrm{~N}, 67.13 \mathrm{~W})$ are presented in Figure 1. There is evidence of an MSD peak in June at both sites, with larger rainfall 


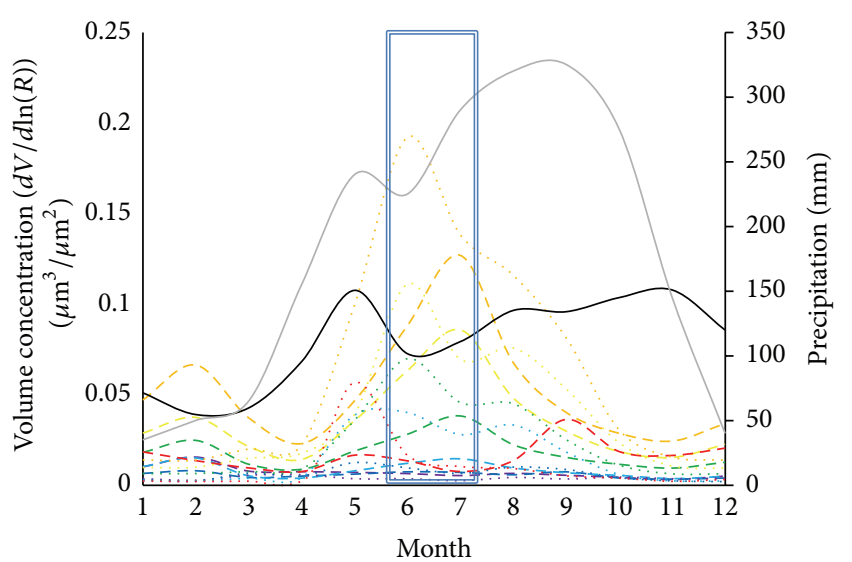

All dashed plots in $\mu \mathrm{m}$

- - - San Juan 0.113

- - - San Juan 0.255

- - - San Juan 0.439

- - - San Juan 0.756

San Juan 1.302

- - San Juan 2.241

- - - San Juan 8.713

...... Mayagüez 0.113

___ Precipitation for Mayagüez

FIGURE 1: Monthly precipitation climatology (1979-2014) and AERONET aerosol volume concentration for various radii at Mayagüez (2012-2015) and at San Juan (2005-2015). Solid lines represent precipitation for Mayagüez (grey) and San Juan (black). Short-dashed plots represent aerosol data for Mayagüez; longdashed plots represent aerosol data for San Juan. Rectangular box encloses the MSD. The precipitation climatology (solid lines) is shown along with available aerosol particle size distribution (PSD) data (dashed lines).

reductions during the MSD in San Juan than in Mayagüez, which are both located on the leeside of the central mountain range that readily produces precipitating orographic clouds and also experience confluent convection, which produces double the amount of precipitation on the western coast compared to the eastern upstream coast [8]. The precipitation climatology is shown along with available aerosol particle size distribution (PSD) data, which shows evidence of an increase in particles with radii between 0.439 and $2.241 \mu \mathrm{m}$ during the MSD.

Jaenicke and Schütz [9] observed that SD radii may range from less than 0.5 to $50 \mu \mathrm{m}$ or larger. Although this is within the range of effective cloud condensation nuclei (CCN), work by Li-Jones et al. [10] has shown that SD is not effective CCN up to a humidity level of $83 \%$. If however sulfur gas and calcium coat the dust, SD may become more hygroscopic and promote droplet growth [11]. Although dust coating is not addressed in this paper, this could facilitate the enhancement of cloud microphysical processes including condensation and collision coalescence.

It has been estimated that 20 percent of the SD from a dust storm originating in western Africa may reach as far as the eastern Atlantic Ocean, while four percent of the total dust amount may reach all the way to the western Atlantic [12]. Dust measurements taken during the July 2000 Puerto Rico Dust Experiment (PRIDE, [13]), some 8 million

tons, equaled about one-fifth of the total deposit for that year. With these amounts of SD in the atmosphere, it is possible that reduced precipitation may be better explained as suppression - the momentary reduction in precipitation that can lead to intense precipitation events if the cloud-aerosol system elevates to an atmospheric level with temperatures low enough to freeze water droplets. Freezing enhances precipitation because water vapor condenses onto ice particles more easily than onto liquid water droplets and can increase the rate of autoconversion. Storm clouds can contain updrafts so strong that melted ice particles near the surface can be pulled back up into the cloud and refreeze. This process can be repeated a number of times, leading to the formation of large, layered hailstones.

While the presence of SD can impact convection in the marine layer, it does not act alone to modify airflow. When the VWS, defined as the wind gradient between two different atmospheric pressure levels, is low, convection is enhanced and the development of rain producing storms is likely to occur [14]. VWS can be weakened due to cumulus penetration by vertical momentum transport and strengthened due to baroclinicity increases, for example, an atmosphere, in which density dependence on temperature and pressure increases [4]. The west coast of Puerto Rico is a particularly interesting case study during heavy dust days, as the rain reducing effect of the dust competes with the precipitation enhancement and VWS reducing effect of the sea breeze/trade wind convergence.

As SD appears to be a major influencing factor in Caribbean precipitation, this paper focuses on the impacts of SD on convection and precipitation over western Puerto Rico during the MSD. The western coast often experiences convergence episodes between the trade winds and surface heating induced westerly sea breeze, producing intense localized late afternoon storms on the western part of the island during the summer months. Also noted as a large contributor to the Puerto Rican water cycle is the production of rain from orographic clouds that form over the central mountain range. National Weather Service (NWS) radar data for precipitation totals during June and July 2014 in Figure 2 reveals higher monthly accumulations over El Yunque (18.32 N, 65.78 W), which is at the extreme east, and west of Arecibo $(18.38 \mathrm{~N}$, $66.63 \mathrm{~W})$ along the central axis of the island $(18.21 \mathrm{~N})$ than at other areas on the island.

This work combines modeling efforts with local observations to improve understanding of SD impacts on local convective processes. A west coast field campaign centered at the western city of Mayagüez was conducted to attain in situ data via radiosondes along with data from a three-channel light detection and ranging (LIDAR) setup, a ceilometer, NWS NEXRAD, and AERONET measurements between 3 June and 15 July 2014. The observations were used to support experiments conducted with the Regional Atmospheric Modeling System (RAMS) under "SD" and "no SD" conditions. Events simulated with RAMS were selected on the basis of ensuring that a range of relevant atmospheric conditions were investigated, including localized and islandwide precipitation events (17 June and 11 July, resp.), lightmoderate days with aerosol optical thickness (AOT) values 

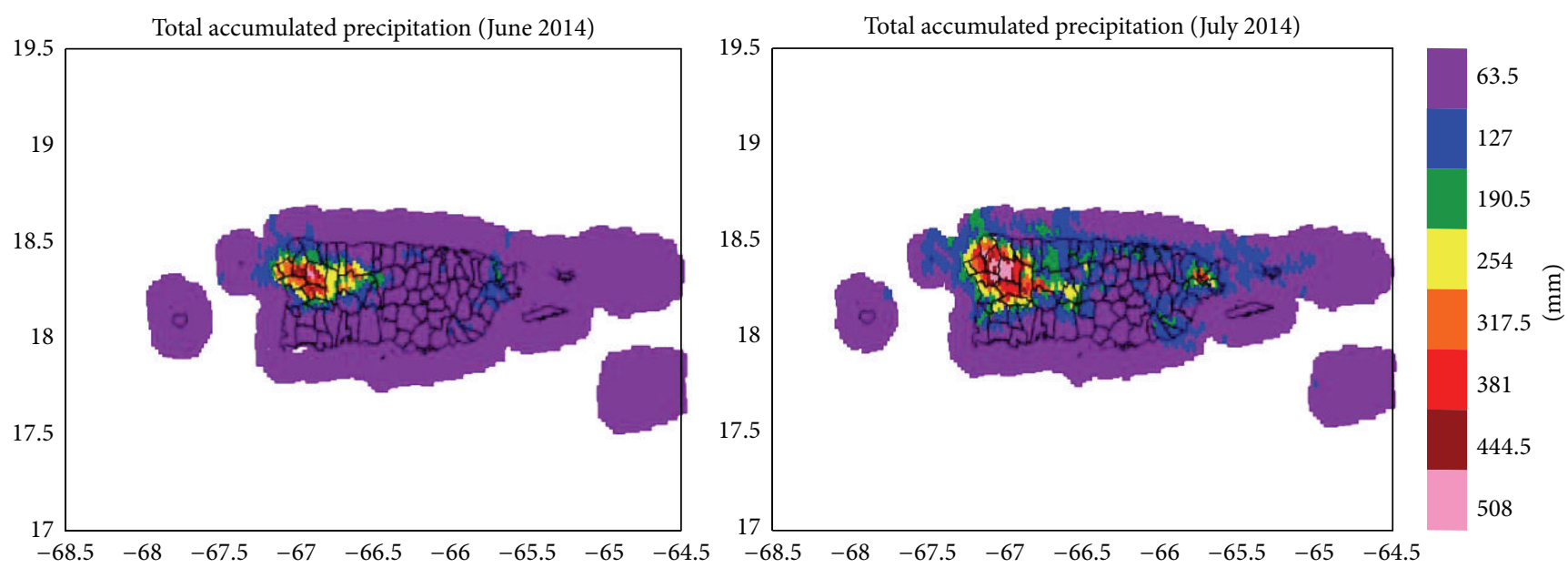

FIgURE 2: Total accumulated precipitation over Puerto Rico for June and July 2014.

below 0.5 and heavy SD days with AOT values above 0.5 (12 and 17 June, resp.), and at least one dry day with no precipitation occurring across the island (7 July 2014).

Given the effect of increased concentrations of aerosols with low solubility on precipitation and convection, the authors hypothesize that changes in SD will modify precipitation and associated dynamical processes including dew point temperature and wind speed and direction in the planetary boundary layer (PBL). From this stance, the fundamental science questions to be investigated in this paper are as follows: (1) To what degree do aerosols and SD impact convection and precipitation in warm environments? (2) Can the presence of SD delay warm precipitation, resulting in more intense cold precipitation hours later?

The paper will unfold as follows; methods and data are described in Section 2, results for the observations and numerical simulations are presented in Section 3, and a discussion and conclusions follow in Section 4.

\section{Methods}

The work outlined in the previous section requires a description of the events to be modelled and the preparation and synchronization of multiple instruments and data from different sensors/sources. The instruments and data are described in the next subsection, followed by an explanation of the RAMS model configuration.

2.1. Radiosondes and AERONET. On specified days, radiosondes were launched from the roof of one of the buildings at the University of Puerto Rico, Mayagüez Campus (UPRM) at either 0800 AST to coincide with launches at the NWS, 1100 AST to capture the late morning instability of the atmosphere, or 1500 AST to capture the afternoon sea breeze. The radiosonde launch schedule and campaign rain/SD particulars for each day are listed in Table 1. As AERONET sun photometers (CIMEL Electronique 318A) operated during daytime, they could often retrieve column averaged AOT [15] during radiosonde flights. PSD may be calculated via inversion of multiwavelength AOT, as described by Dubovik and King [16] and Otero et al. [17]. The AOT product was collected for the 15 campaign days over Mayagüez $(18.20 \mathrm{~N},-67.14 \mathrm{~W})$, La Parguera $(17.97 \mathrm{~N},-67.04 \mathrm{~W})$, and Barbados $(13.16 \mathrm{~N},-59.49 \mathrm{~W})$ where available. AOT values between 0 and 0.1 represented low SD concentrations, values between 0.1 and 0.3 represented moderate SD, values between 0.3 and 0.5 represented moderate-heavy SD, and values above 0.5 represented heavy SD. In addition, PSDs over Mayagüez and La Parguera were attained for 12 June 2014, 17 June 2014, 7 July 2014, and 11 July 2014 for input into RAMS.

To achieve this end, PSDs were converted from volume distributions into number concentrations via the following equation from [18]:

$$
\frac{d V}{d(\log r)}=V(r) * \frac{d N}{d(\log r)},
$$

where

$$
\frac{d N}{d(\log r)}
$$

is the density number log-normal distribution and

$$
\frac{d V}{d(\log r)}
$$

is the volume distribution obtained from AERONET. The volume of each particle (assumed spherical) is

$$
V(r)=\frac{4 \pi}{3} * r^{3},
$$

such that

$$
\frac{d N}{d(\log r)}=\frac{3}{4 \pi r^{3}} * \frac{d V}{d(\log r)} .
$$

SD concentrations were approximated via comparison of the PSD distributions for low and high AOT days. For 
TABLE 1: Radiosonde launches.

\begin{tabular}{|c|c|c|c|c|}
\hline Radiosonde date and time & Maximum height & Rain (Mayagüez) & Dust & Final location \\
\hline 03 June 0800 AST & $24162 \mathrm{~m}$ & Trace & Light & Yauco \\
\hline 12 June 1100 AST & $21461 \mathrm{~m}$ & Trace & Moderate & Lares \\
\hline 14 June 1100 AST & $24595 \mathrm{~m}$ & None & Moderate-heavy & Lares \\
\hline 16 June 0800 AST & $23239 \mathrm{~m}$ & None & Moderate-heavy & Yauco \\
\hline 17 June 1100 AST & $22036 \mathrm{~m}$ & Trace & Heavy & Lares \\
\hline 21 June 1100 AST & $22576 \mathrm{~m}$ & Moderate-heavy & Trace & Maricao \\
\hline 24 June 1100 AST & $25361 \mathrm{~m}$ & Trace & Trace & Ocean ( 20 km west of Mayagüez) \\
\hline 30 June 1100 AST & $20902 \mathrm{~m}$ & Heavy & Moderate & Maricao \\
\hline 1 July 0800 AST & $25558 \mathrm{~m}$ & Heavy & Light & Cabo Rojo \\
\hline 3 July 1100 AST & $15556 \mathrm{~m}$ & Heavy & Trace & Cabo Rojo \\
\hline 7 July 0800 AST & $21183 \mathrm{~m}$ & None & Light-moderate & Añasco \\
\hline 8 July 1100 AST & $22996 \mathrm{~m}$ & Moderate & Light & Rincón \\
\hline 11 July 1100 AST & $24551 \mathrm{~m}$ & Heavy & Moderate & Rincón \\
\hline 12 July 1100 AST & $20296 \mathrm{~m}$ & Moderate & Moderate & Añasco \\
\hline 15 July 1500 AST & 23392 & None & Light & Moca \\
\hline
\end{tabular}

TABLE 2: CCN, GCCN, and SD concentrations.

\begin{tabular}{lcccccc}
\hline Day & $\begin{array}{c}\text { CCN radius } \\
(\mu \mathrm{m})\end{array}$ & $\begin{array}{c}\text { CCN concentration } \\
\left(\text { per cm }^{-3}\right)\end{array}$ & $\begin{array}{c}\text { GCCN radius } \\
(\mu \mathrm{m})\end{array}$ & $\begin{array}{c}\text { GCCN concentration } \\
\left(\mathrm{per} \mathrm{cm}^{-3}\right)\end{array}$ & $\begin{array}{c}\text { SD radius } \\
(\mu \mathrm{m})\end{array}$ & $\begin{array}{c}\text { SD concentration } \\
\left(\mathrm{per} \mathrm{cm}^{-3}\right)\end{array}$ \\
\hline 12 June & .1129 & 226 & 2.241 & 3.017 & 2.241 & 2260 \\
17 June & .1129 & 191 & 5.061 & 0.804 & 5.061 & 1915 \\
07 July & .1129 & 226 & 1.708 & 10.359 & 1.708 & 2260 \\
11 July & .1129 & 104 & 2.241 & 1.418 & 2.241 & 1040 \\
\hline
\end{tabular}

extremely low AOT days (values lower than 0.05), it was assumed that no SD was in the atmosphere. Compared to SD concentrations, concentrations for cloud condensation nuclei $(\mathrm{CCN})$ with radii less than or equal to $1 \mu \mathrm{m}$ and giant CCN (GCCN) with radii larger than $1 \mu \mathrm{m}$ exhibited a scaledown factor of 10. In other words, very high AOT days (above 0.5 ) produced number concentrations 10 times higher than for extremely low AOT days. Results for median radii and concentrations of CCN/GCCN/SD are displayed in Table 2. The sun photometer is the only instrument in this work that operated continuously during the daytime hours. All other instruments were synchronized to collect data at the instant the radiosondes were launched.

2.2. LIDAR and Ceilometer. Three-channel LIDAR data (355, 532 , and $1064 \mathrm{~nm}$ ) was collected for every campaign date except 3 July 2014, since precipitation occurred at the time the radiosonde was launched. LIDAR was operated for one to two hours per day, synchronized with radiosonde ascension. In addition to the three-channel LIDAR system, a Vaisala manufactured CL51 ceilometer employing pulsed diode laser LIDAR technology at $910 \mathrm{~nm}$ is also implemented.

2.3. Satellite, NWS Radar, and GHCN Stations. To determine SD path, coverage, and intensity, images taken by a geostationary meteorological satellite operated by the European Organization for the Exploitation of Meteorological Satellites (EUMETSAT) under the Meteosat Transition Programme
(MTP) and the Meteosat Second Generation (MSG) program were analyzed. NWS total daily accumulated precipitation radar data at $4 \mathrm{~km}$ spatial resolution was also collected. To validate both NWS radar data and RAMS precipitation results, 57 island-wide GHCN stations were included in order to track precipitation totals. The GHCN sites and their locations are shown in Figure 4(a). Important sites include Mayagüez (M), Lares (L), Arecibo (AR), Adjuntas (AD), San Juan (SJ), La Parguera (LP), and El Yunque (EY).

2.4. Rams Modeling. RAMS version 6.1.1 [19] is used to simulate four campaign events under "SD" and "no SD" conditions. The model domain includes two nested grids at 5 and $1 \mathrm{~km}$ horizontal grid spacing, respectively. Each simulation has 35 vertical levels, the long time-step is $30 \mathrm{~s}$, and the short time-step is $5 \mathrm{~s}$. North American Regional Reanalysis (NARR) data [20] at $32 \mathrm{~km}$ resolution is assimilated to provide initial and boundary conditions, with boundary conditions updated every 3 hours.

Surface processes were parameterized using the Land Ecosystem-Atmosphere Feedback model (LEAF-3, [2]), a RAMS submodel that evaluates energy and water budgets at the surface. Sea surface temperature (SST) was derived from the Smith and Reynolds Extended Reconstruction Sea Surface Temperature (ERSST v3b, [21]). SST values, which are normally updated on a monthly basis, were assumed constant for the short duration of the simulations conducted herein. The Mahrer and Pielke [22] scheme was used for short and long wave radiation due to low cloud top heights during the 


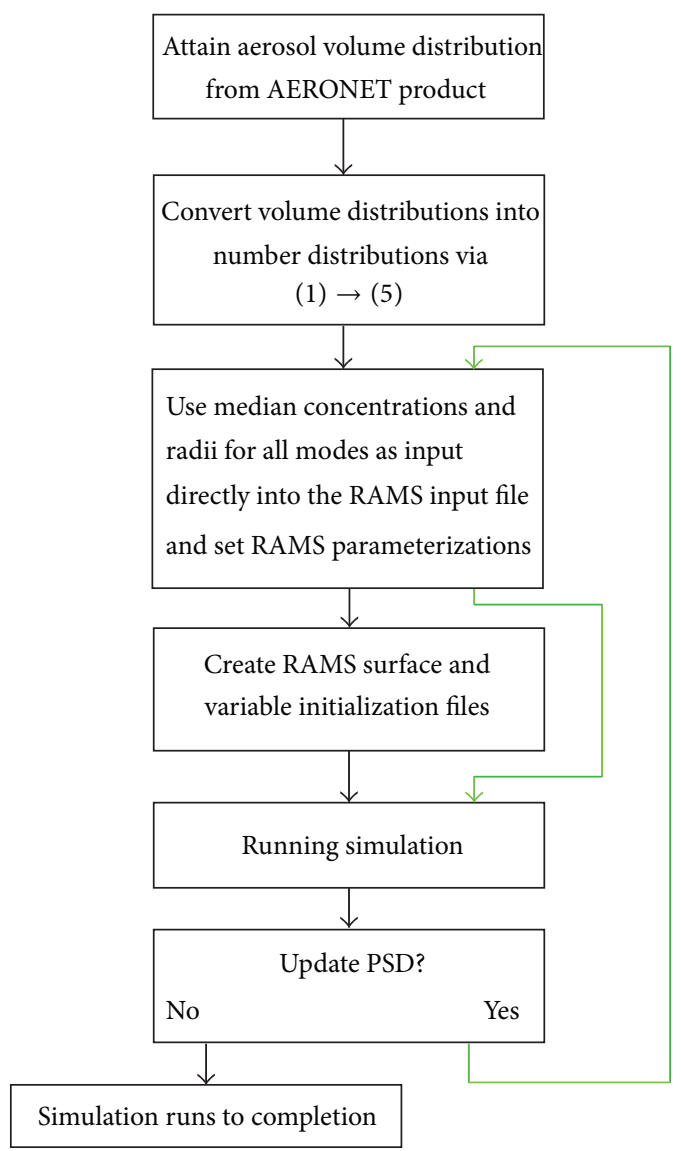

FIGURE 3: RAMS simulation setup flow chart for PSD ingestion.

days selected for simulation. For grid 2, an explicit cloud microphysics scheme [19] is used.

The two-moment microphysical scheme includes all categories of water in the atmosphere and predicts hydrometeor mass mixing ratio and number concentrations for nine possible aerosol species, of which the important ones for this study include submicrometer sulfate, supermicrometer sulfate, submicrometer mineral dust, and supermicrometer mineral dust. Each species has a characteristic solubility with dust nearly fully insoluble, salt nearly fully soluble, and sulfate-based particles varying over the scale. There are discrete distribution bin size ranges for each represented median radius in the Lagrangian parcel model and in the lognormal distribution representation.

Aerosol median radii and concentrations of the PSDs attained from AERONET via (1) through (5) were ingested into RAMS as input variables and updated when available. Values of the PSD inputs are shown in Table 2. Variable initiation files for each run were then created, and the model simulations were initiated. A diagram of the simulation setup process is shown in Figure 3. 12 and 17 June were short events lasting less than 3 hours, while the dry 7 July event was considered a 24 -hour event and 11 July produced rain intermittently over a 15 -hour period. All events were run for 24 hours. Past simulations using National Center for Environmental Prediction (NCEP, [23]) data have shown

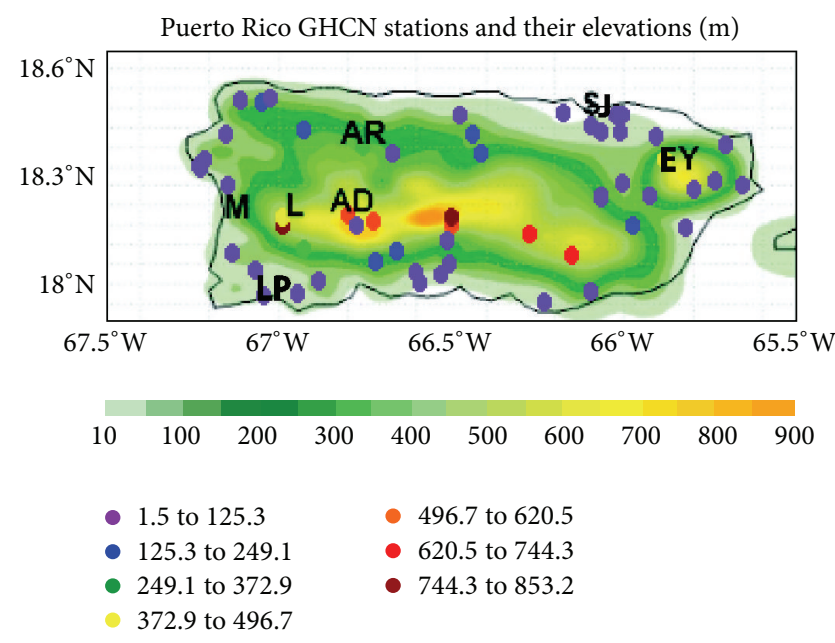

(a)

Western Puerto Rico radiosonde launch and termination points

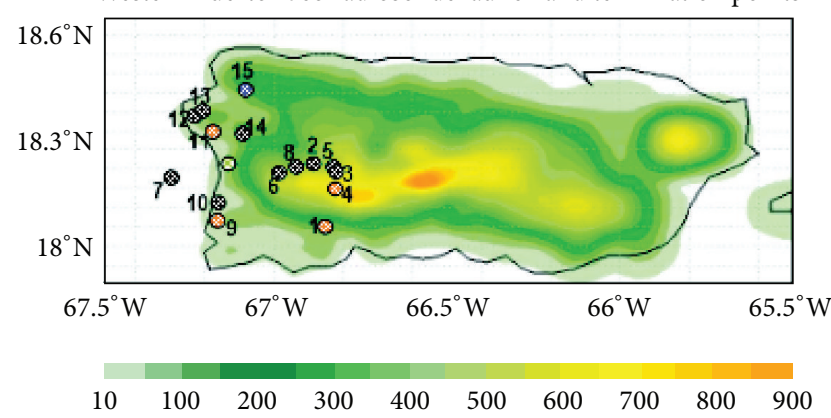

(b)

FIgURe 4: Sites and locations over Puerto Rico. (a) GHCN weather station locations and important city sites. Mayagüez (M), Lares (L), Arecibo (A), Adjuntas (AD), San Juan (SJ), and El Yunque (EY) are denoted by the letters $\mathrm{M}, \mathrm{L}, \mathrm{AR}, \mathrm{AD}, \mathrm{S}$, and $\mathrm{Y}$, respectively. (b) Radiosonde launch and termination points. The black circle with the green " $x$ " denotes the radiosonde launch site, black circles with orange crosshatching denote the 0800 AST launch termination points, black circles with black crosshatching denote 1100 AST termination points, and the black circle with blue crosshatching denotes the 1500 AST termination point.

TABLE 3: RAMS ensemble.

\begin{tabular}{lcc}
\hline Simulation ID & Date & SD \\
\hline 1 & 12 June 2014 & No \\
2 & 12 June 2014 & Yes \\
3 & 17 June 2014 & No \\
4 & 17 June 2014 & Yes \\
5 & 07 July 2014 & No \\
6 & 07 July 2014 & Yes \\
7 & 11 July 2014 & No \\
8 & 11 July 2014 & Yes \\
\hline
\end{tabular}

that RAMS precipitation can lag observations by 6 hours or more [24]. With the NARR data updating the simulations every three hours, this lag dissipates. The complete numerical ensemble is shown in Table 3. 

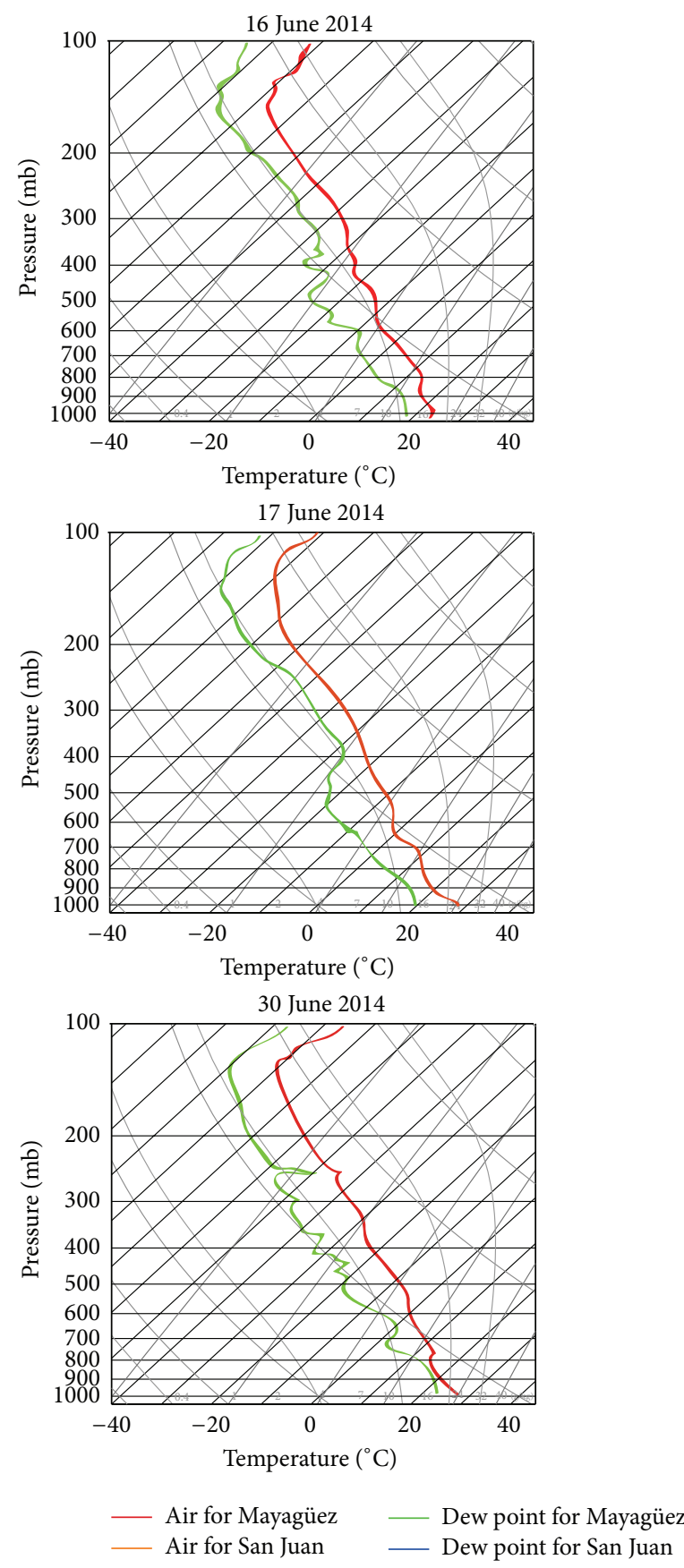

(a)
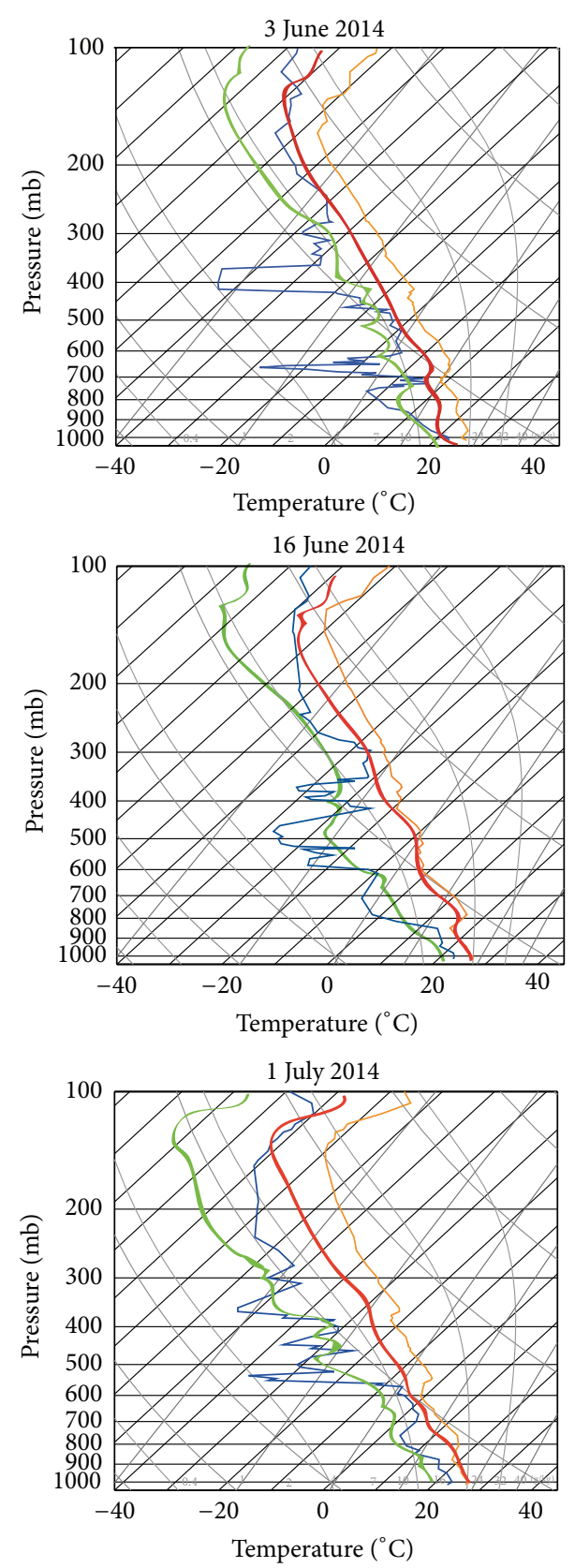

$\begin{array}{ll}\text { — Air for Mayagüez } & \text { _ Dew point for Mayagüez } \\ \text { _ Air for San Juan } & \text { - Dew point for San Juan }\end{array}$

(b)

Figure 5: (a) Skew-T plots for heavy SD days over Mayagüez. (b) Skew-T plots for 0800 AST (3 and 16 June 2014 and 1 July 2014 ) launches over Mayagüez and San Juan.

\section{Results and Discussion}

After describing the results of the campaign, the atmospheric conditions for 12 and 17 June 2014 and 7 and 11 July 2014 will be presented. Results for the RAMS simulations will then follow.

3.1. Observational Results. One radiosonde failed to collect data between 0.1 and $2 \mathrm{~km}$ (24 June 2014), while all others were able to transmit data to the ground station for the durations of their respective flights. All terminated within a $36 \mathrm{~km}$ radius from the initial launch point in Mayagüez (Figure 4(b)). Nine radiosondes fell east of the launch point, three fell less than $5 \mathrm{~km}$ west, and three more fell over $10 \mathrm{~km}$ west. Investigation of the vertical wind structure attained from the radiosondes shows that the sea breeze reached upwards of $9 \mathrm{~m} \mathrm{~s}^{-1}$. Low level temperature inversions 

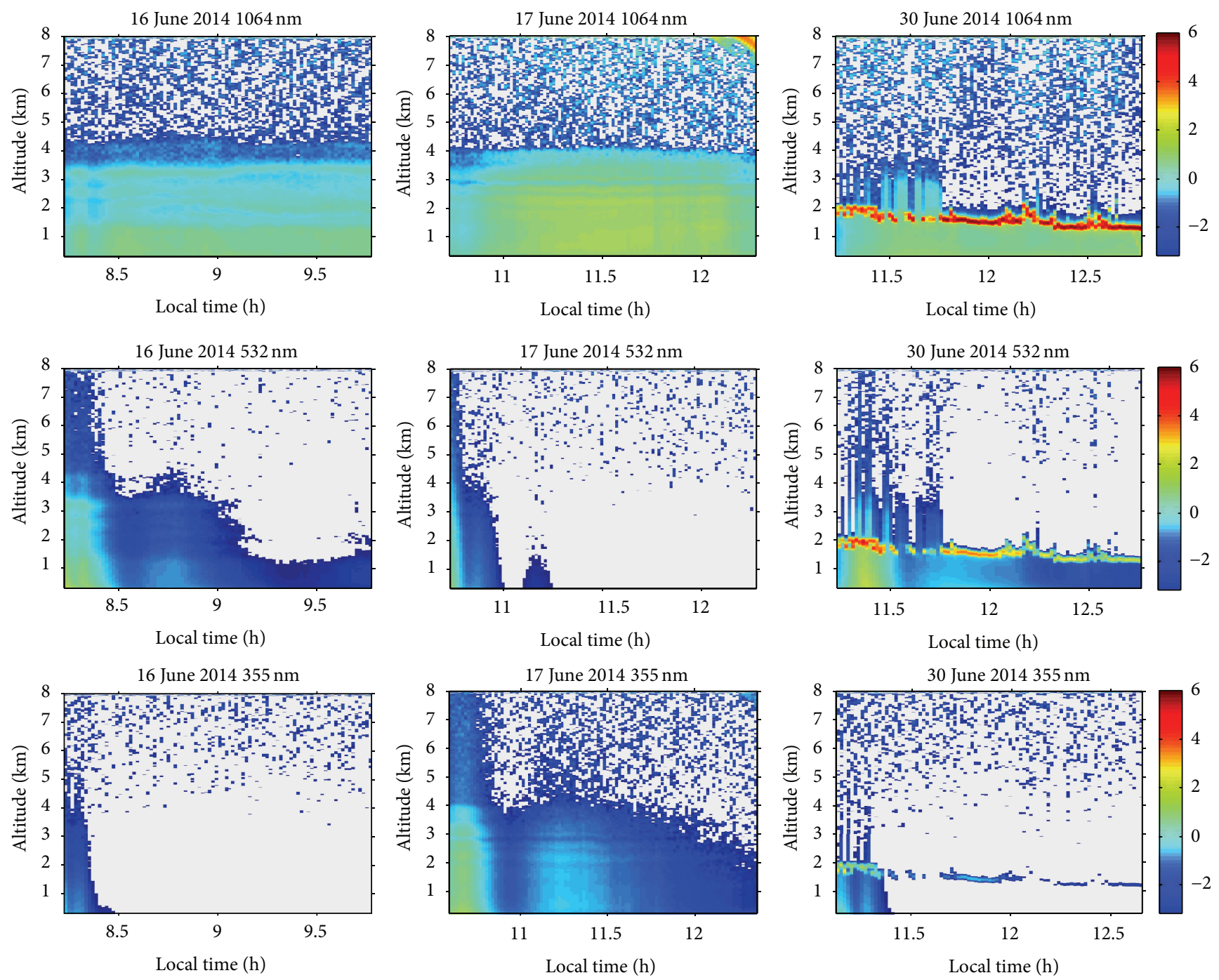

FIGURE 6: LIDAR returns. Color scale represents signal intensity.

between 1 and $4 \mathrm{~km}$ are identified during heavy and moderate SD days and indicate convective instability in the PBL. SkewT diagrams for the 16, 17, and 30 June 2014 UPRM launches are presented in Figure 5(a), while the 0800 AST NWS and UPRM radiosonde launches are shown in Figure 5(b). This provides evidence that the western side of the island is more humid than the eastern side.

LIDAR imagery in Figure 6 shows high aerosol intensity for the $1064 \mathrm{~nm}$ wavelength during heavy SD episodes $(16,17$, and 30 June 2014), corroborated with Meteosat imagery (not shown). The 355 and $532 \mathrm{~nm}$ wavelengths show less activity during heavy SD episodes. Cloud heights attained from LIDAR backscatter plots coincide with meeting points of dew point and environmental temperature lines on the skew-T diagrams previously discussed and presented in Figure 5 and ranged from 1.5 to $3.5 \mathrm{~km}$ during campaign.

AOT measured at the La Parguera (when available) and Mayagüez AERONET sites during the campaign yielded 1 day with AOT values between 0 and 0.1 (low SD concentrations), 4 days with values between 0.1 and 0.3 (moderate SD concentrations), 4 days with values between 0.3 and 0.5 (moderateheavy SD concentrations), and 6 days with values above 0.5 (heavy SD concentrations). AOT at the Barbados AERONET site east of Puerto Rico shows higher values of AOT than in Mayagüez and La Parguera for 73\% of the launches possibly suggesting dissipation of the SD concentration as the dust travels westward.

Between 3 June and 15 July 2014, there were 13 precipitation events which produced at least $38 \mathrm{~mm}$ of rain over at least $10 \%$ of the island according to GHCN station data and NWS radar. Eight of the events were local events concentrated over western Puerto Rico, and the remaining five were island-wide events (with four events having higher totals on the west than in the east). NWS radar for total accumulated precipitation over Puerto Rico during June 2014 shows that the western side of the island tended to have higher rainfall accumulations 
Total accumulated precipitation
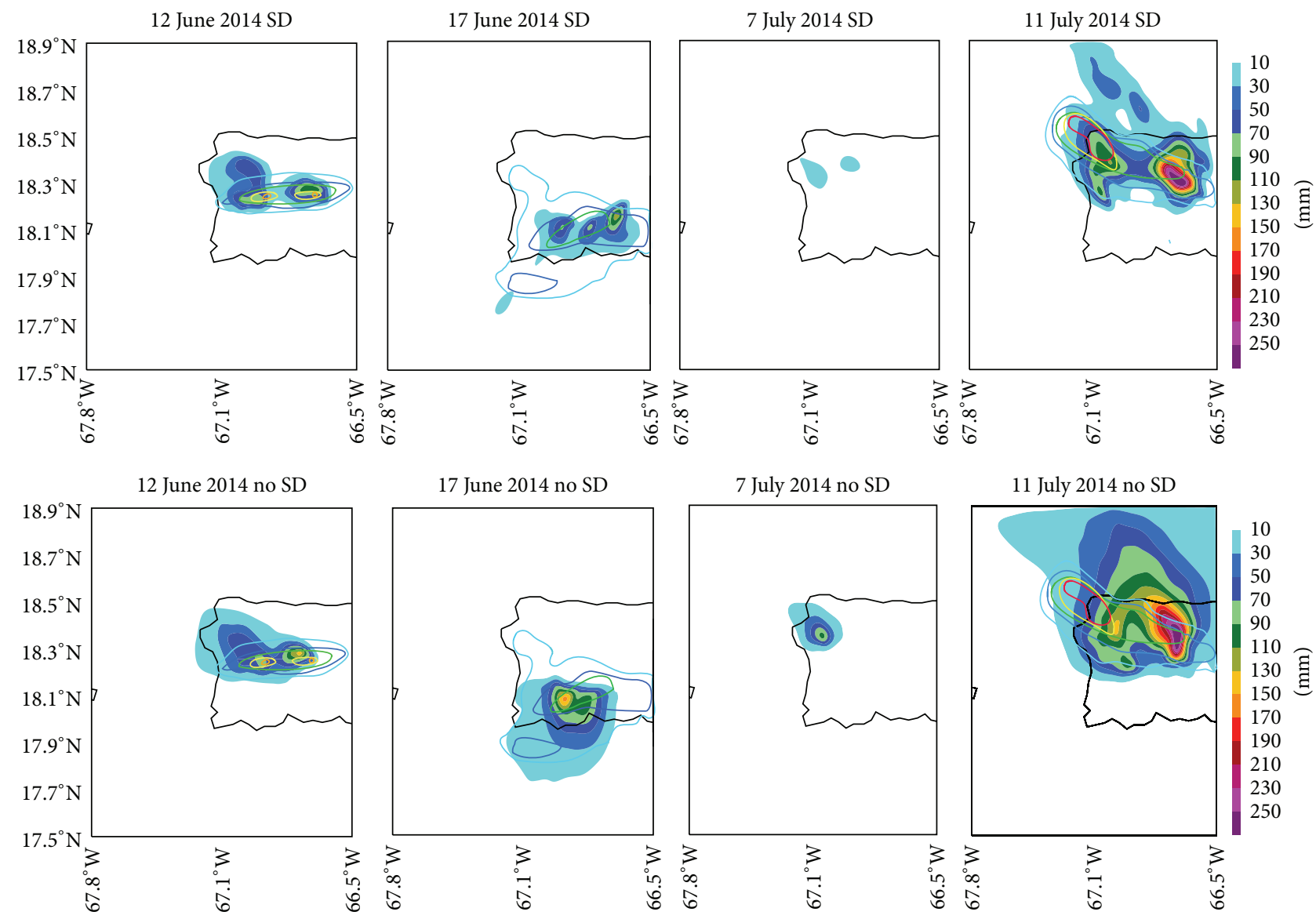

FIgURE 7: Total accumulated precipitation from RAMS (shaded) compared with NWS radar (contours).

than the east during this period. The synoptic setup for the RAMS modeled events is described below.

3.1.1. 12 June 2014 (Localized Moderate Rain, Moderate-Heavy $S D)$. This rainfall event lasted three hours, concentrated on the western side of the island, with the orographic effect evident along the central mountain range band $(18.20 \mathrm{~N}$ latitude). The highest total accumulated precipitation was observed in Lares $(18.30 \mathrm{~N}, 66.88 \mathrm{~W})$, a total of $107 \mathrm{~mm}$. At the eastern edge of the island, the convective available potential energy (CAPE) was $644 \mathrm{~J} \mathrm{~kg}^{-1}$ as measured by the $0800 \mathrm{AST}$ NWS radiosonde, indicating a stable, dry atmosphere with a low likelihood of thunderstorms. The average AOT in the column as measured from the Barbados AERONET site was 0.584 . Westward, the $1064 \mathrm{~nm}$ LIDAR wavelength indicates light dust in the vertical column. The atmosphere was more humid than in the east, the CAPE was $950 \mathrm{~J} \mathrm{~kg}^{-1}$ at $1100 \mathrm{AST}$, and the VWS between 850 and $700 \mathrm{mb}$ and between 850 and $500 \mathrm{mb}$ were 2 and $0.556 \mathrm{~s}^{-1}$, respectively. The average AOT over Mayagüez was 0.324 .

3.1.2. 17 June 2014 (Island-Wide Light Rain, Heavy SD). A precipitation event on this day lasted four hours with light to moderate rainfall concentrated southwest and northeast. The highest total accumulated rainfall was observed south of Adjuntas $(18.16 \mathrm{~N}, 66.72 \mathrm{~W})$, a total of $57 \mathrm{~mm}$. At the eastern edge of the island, the CAPE was $1261 \mathrm{~J} \mathrm{~kg}^{-1}$, and the atmosphere was dry from 850 to $400 \mathrm{mb}$. The average AOT in the column as measured from the Barbados AERONET site was 1 . Westward, the $1064 \mathrm{~nm}$ LIDAR wavelength indicates heavy dust presence between the surface and $4 \mathrm{~km}$. The western atmosphere was more humid than in the east, the CAPE was $627 \mathrm{~J} \mathrm{~kg}^{-1}$ at $1100 \mathrm{AST}$, and the VWS between 850 and $700 \mathrm{mb}$ and between 850 and $500 \mathrm{mb}$ were 2.7 and $0.79 \mathrm{~s}^{-1}$, respectively. The average AOT over Mayagüez was 0.726 .

3.1.3. 7 July 2014 (Island-Wide Dry, Heavy SD). There was no precipitation over the island on 7 July 2014. The surface pressure map indicates northeasterly flow into the island at nearly constant pressure. The atmosphere is dry throughout the column, although the CAPE is $1492 \mathrm{~J} \mathrm{~kg}^{-1}$ at 0800 AST. VWS between 850 and $700 \mathrm{mb}$ and between 850 and $500 \mathrm{mb}$ were 2 and 1, respectively. Eastern VWS values were only calculated for this case because the 0800 AST NWS radiosonde launch coincides with the westward UPRM launch. The average AOT 
Surface winds

12 June 2014

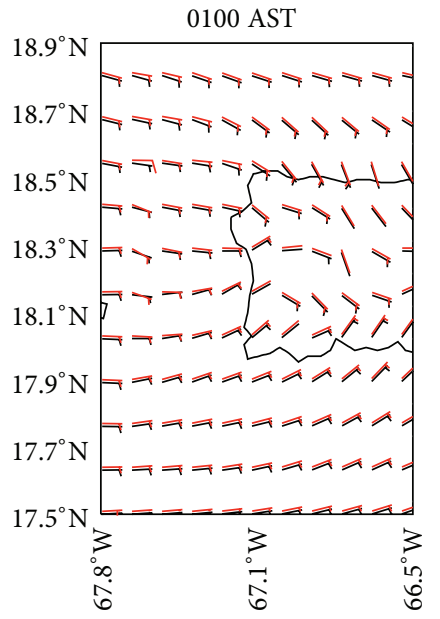

7 July 2014

0100 AST

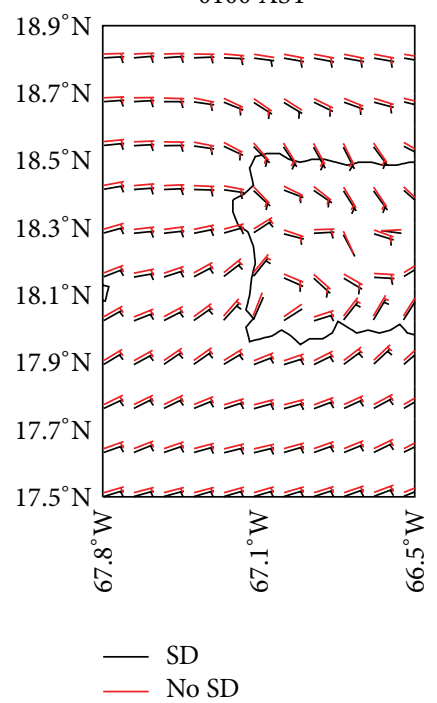

17 June 2014

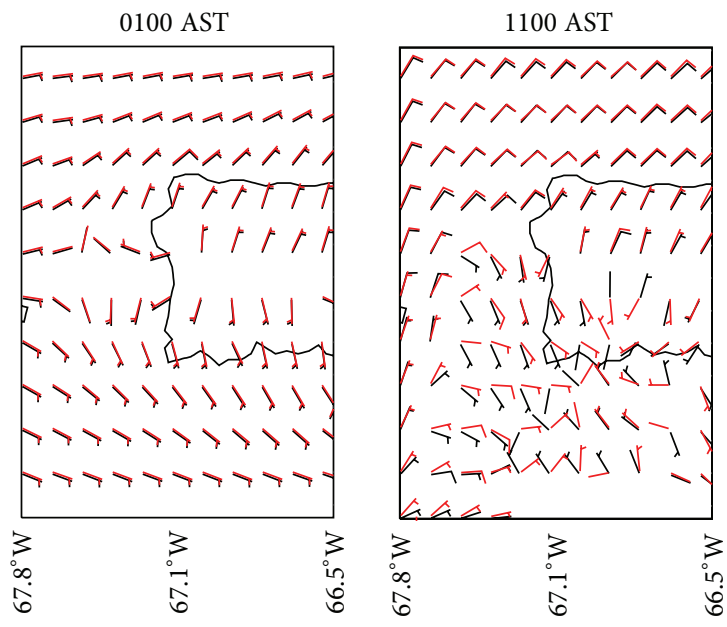

11 July 2014
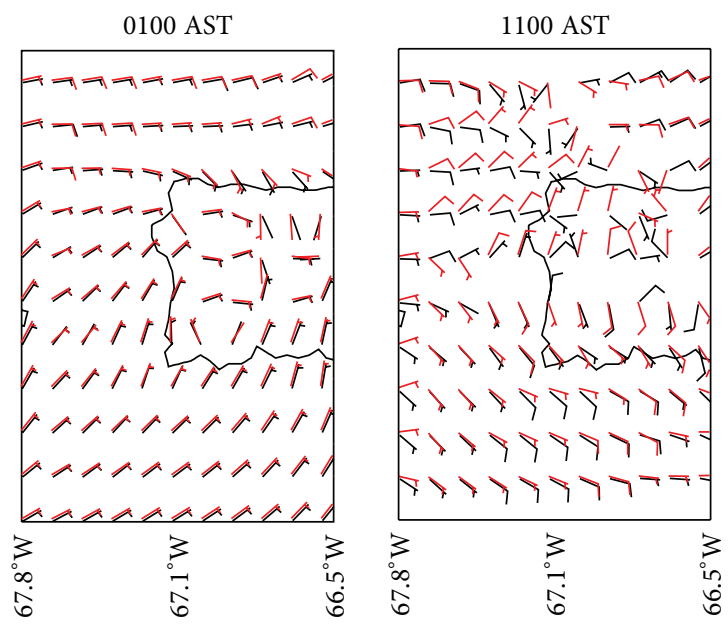

FIGURE 8: RAMS generated wind barbs near the surface at two different times (0100 and 1100 AST) for all runs. Black barbs denote SD results, and red barbs denote no SD results.

over Barbados was 0.258. Westward, the $1064 \mathrm{~nm} \mathrm{LIDAR}$ wavelength indicates heavy dust between the surface and $1 \mathrm{~km}$. The atmosphere was more humid than in the east, the CAPE was $1800 \mathrm{~J} \mathrm{~kg}^{-1}$ at $0800 \mathrm{AST}$, and the VWS between 850 and $700 \mathrm{mb}$ and between 850 and $500 \mathrm{mb}$ were 0.6 and $1.7 \mathrm{~s}^{-1}$, respectively. The average AOT over Mayagüez was 0.512 .

\subsubsection{July 2014 (Island-Wide Heavy Rain, Light-Moderate} SD). On 11 July, 2014 rain fell on and off over a 15-hour period. While rainfall was island-wide, precipitation totals surpassing $150 \mathrm{~mm}$ occurred in San Juan and in the northwest region enclosed within the region bounded by $18.30 \mathrm{~N}-18.60 \mathrm{~N}$ and $68.00 \mathrm{~W}-67.40 \mathrm{~W}$. The CAPE was $2212 \mathrm{~J} \mathrm{~kg}^{-1}$, indicative of a high possibility of thunderstorm occurrence. The average AOT over Barbados was 1.335. Westward, the $1064 \mathrm{~nm}$ LIDAR wavelength indicates heavy dust between the surface and $2 \mathrm{~km}$. The CAPE was $2635 \mathrm{~J} \mathrm{~kg}^{-1}$ at $1100 \mathrm{AST}$, and the VWS between 850 and $700 \mathrm{mb}$ and between 850 and $500 \mathrm{mb}$ were -0.67 and $0.89 \mathrm{~s}^{-1}$, respectively. The average AOT over Mayagüez was 0.226 . The fourfold decrease of AOT in the west compared with the eastern value is attributed to reduced dust in the PBL after the occurrence of rain.

3.2. Rams Simulations. All RAMS simulations produced the general spatial orientation of observed total accumulated precipitation attained from NWS and GCHN stations (Figure 7). Runs with no SD produced higher precipitation totals and tended to aggregate storm cells that were initially separate. The 12 June 2014 control run (with SD) produces rain along the central mountain range. When SD is removed, 
Dew point temperature differences

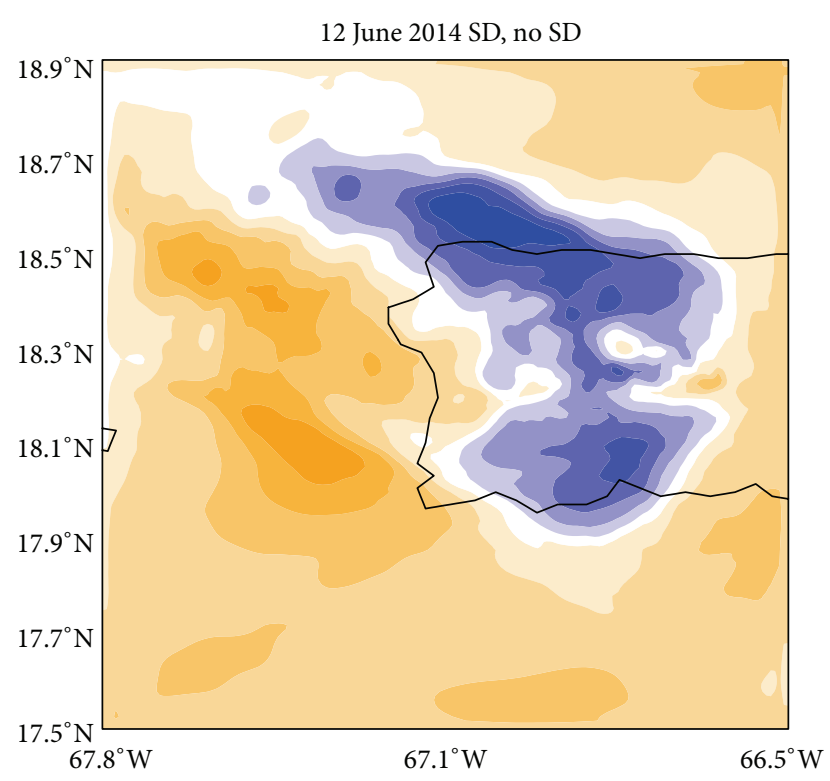

(a)

7 July 2014 SD, no SD

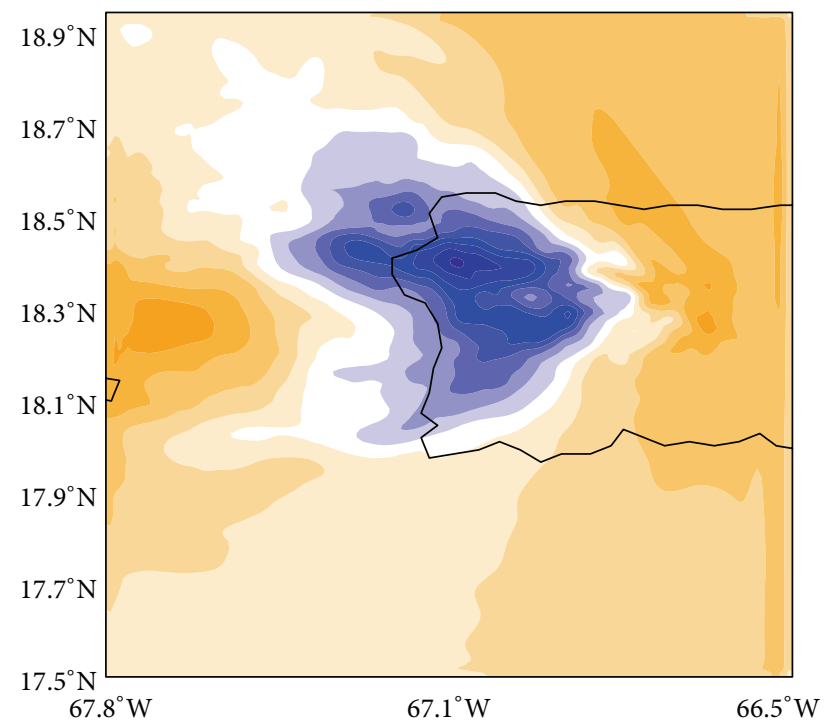

(c)

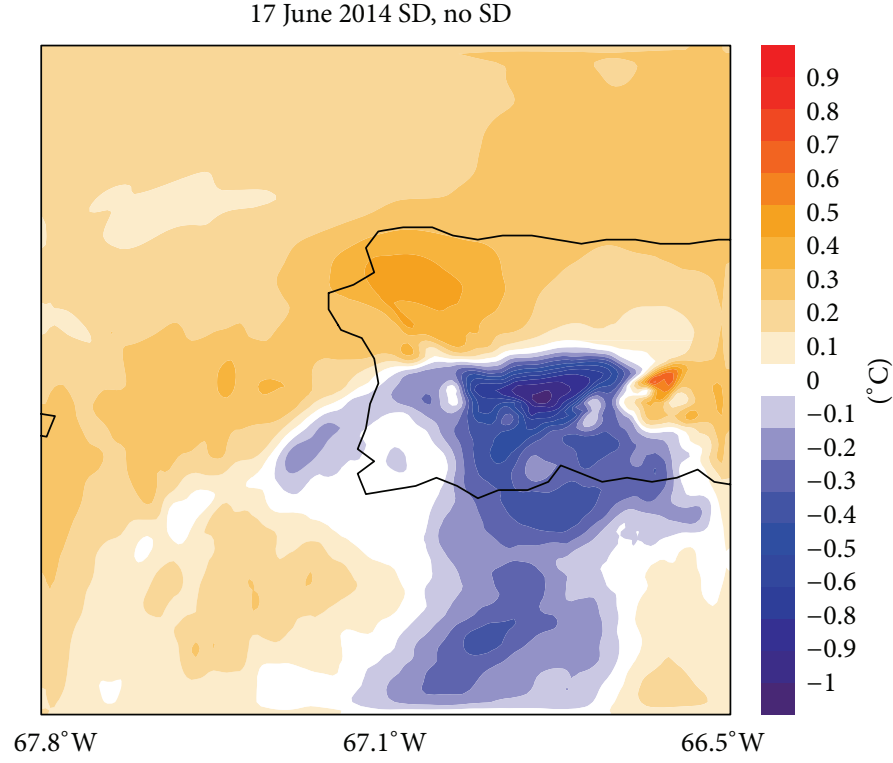

(b)

11 July 2014 SD, no SD

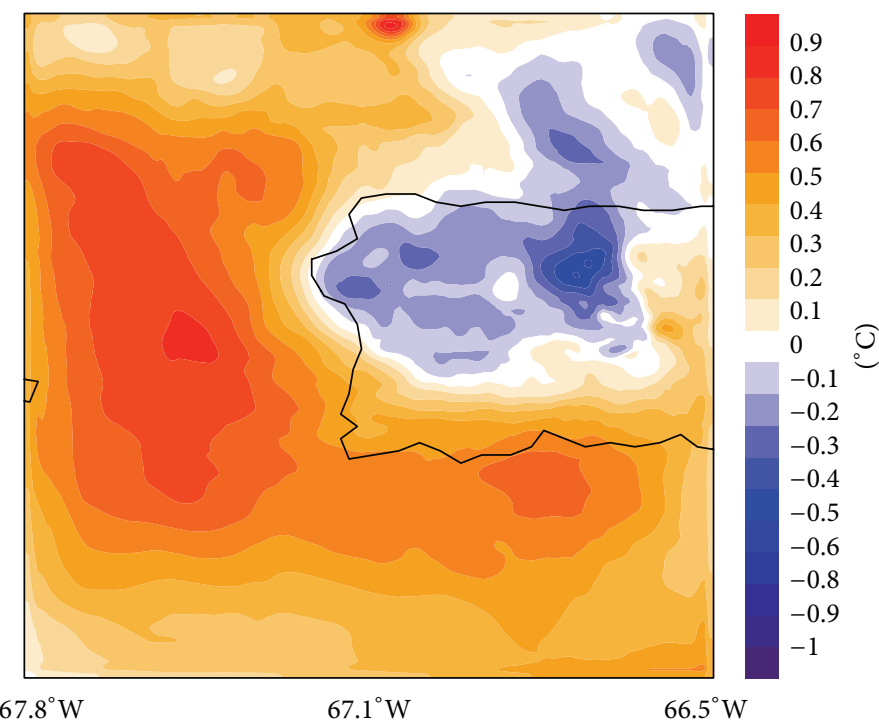

(d)

Figure 9: RAMS generated dew point temperature differences between SD and no SD run for 12 June 2014 (a), 17 June 2014 (b), 7 July 2014 (c), and 11 July 2014 (d).

precipitation over mountain range increases. The 17 June 2014 control run produced precipitation along the western edge of the central mountains. Two cells of moderate rain are connected by a low precipitation band (less than $10 \mathrm{~mm}$ ), in agreement with NWS radar. Removal of the SD again increases precipitation accumulation and broadens the rainfall area. Orography plays a large role in the 12 and 17 June 2014 events. If the model topography were modified in such a way that the mountains were removed, less rainfall for these two events would be likely. For the 7 July 2014 event, the model control run (with SD) produces light rain in the northeast of the island despite a lack of precipitation according to NWS and GHCN data. When SD is removed, precipitation is increased 10-fold. The 11 July 2014 control run produces heavy precipitation (over $80 \mathrm{~mm}$ ) at the north central and northwestern areas. The removal of SD in this case extends the precipitation northward, $\sim 25 \mathrm{~km}$ into the Atlantic Ocean. This leads to an analysis of the winds, as any change can alter storm position and sea breeze strength.

Figure 8 shows wind barbs near the surface at two different times (0100 and 1100 AST) for all runs. This plot captures the beginning of the sea breeze formation and reveals that the 
Cloud fraction differences

12 June 2014 SD, no SD

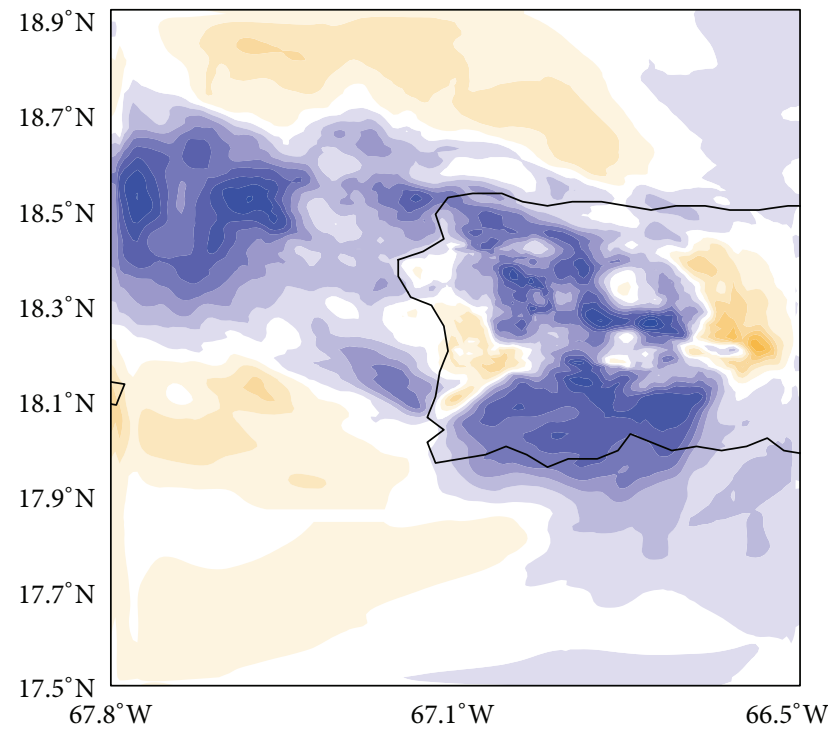

(a)

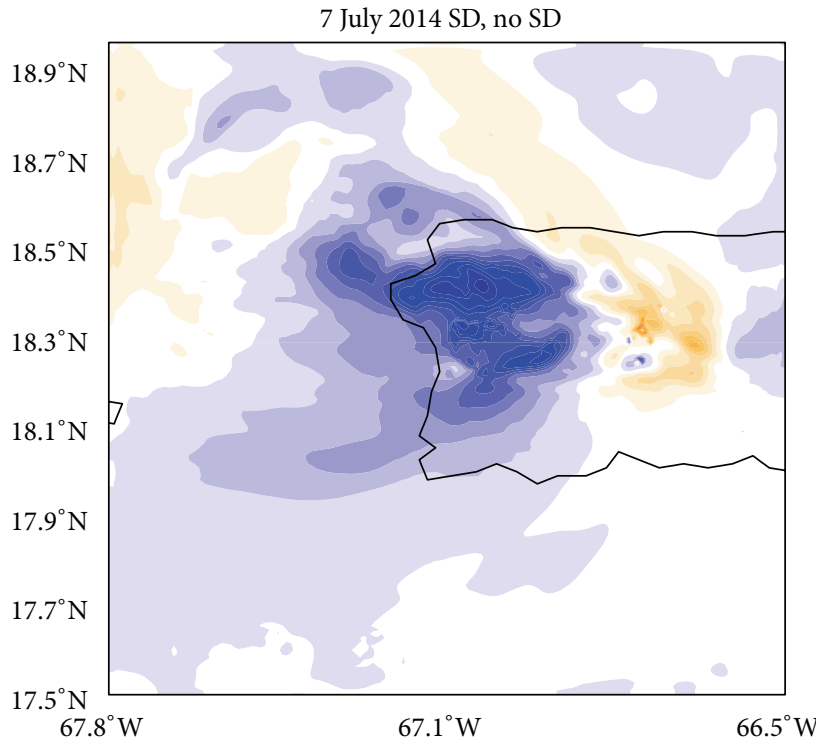

(c)
17 June 2014 SD, no SD

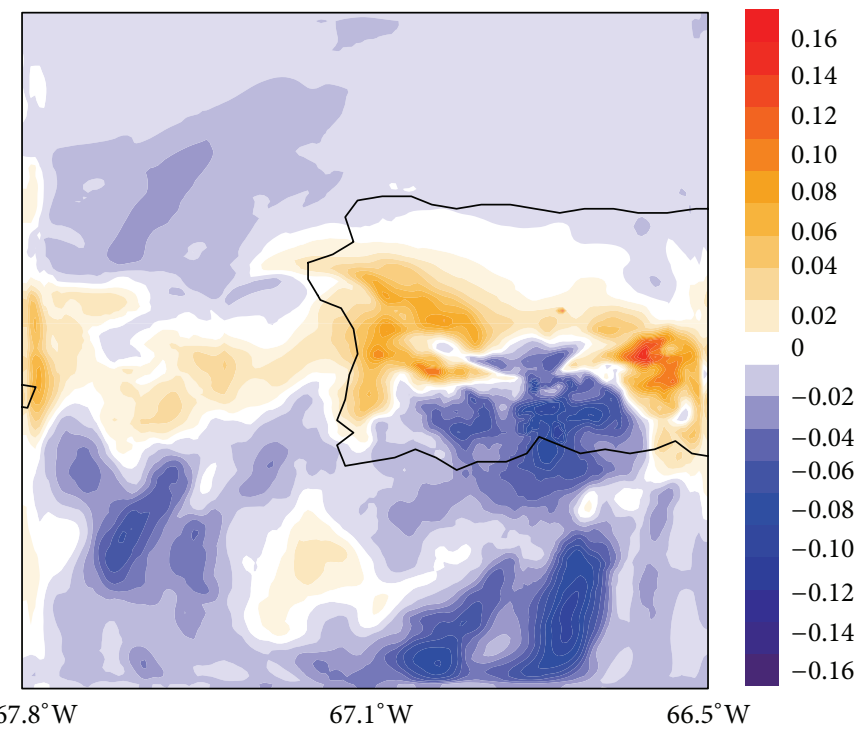

(b)

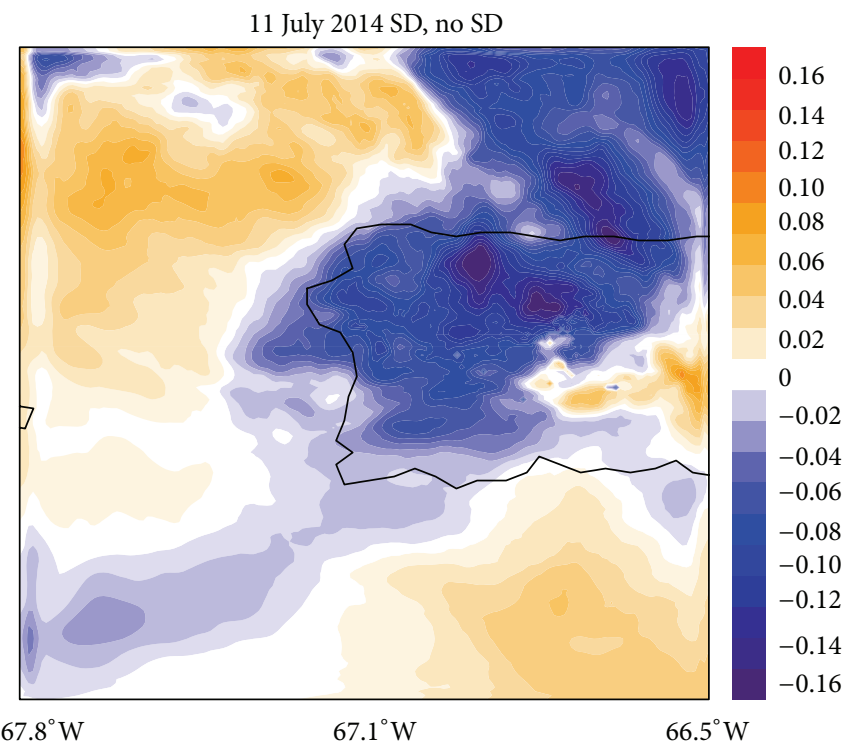

(d)

FIGURE 10: RAMS generated cloud fraction differences between SD and no SD runs for 12 June 2014 (a), 17 June 2014 (b), 7 July 2014 (c), and 11 July 2014 (d).

SD presence impacts winds between 0100 and 1100 AST in all cases. Note that winds are modified in all cases here, not only for the moderate-heavy dust events. Dew point differences between SD and no SD runs in Figure 9 show definitive evidence that the presence of SD reduces dew point temperature averaged in the PBL at locations with high precipitation (Figure 7). Under conditions of comparable environmental temperature, dew point temperature decreases along with reduced convection due to sea breeze hindrance reducing the possibility of rainfall. A direct impact of these is a reduction in cloud coverage. The cloud fraction differences between SD and no SD runs shown in Figure 10 are consistent with the previous observation and are indicative of inhibited cloud formation during extreme dust episodes.

Vertical wind difference averages between "no SD" and "SD" in Figure 11 show changes at the locations of rainfall for each run. Increases and decreases along the $18.21 \mathrm{~N}$ latitude are shown for 17 June 2014, whereas, for 11 July 2014, increases of vertical winds $\left(0.4-0.8 \mathrm{~m} \mathrm{~s}^{-1}\right)$ over the central location of the storm are shown, with decreases on the outer perimeter. Smaller changes are shown for the 12 June 2014 and 7 July 2014 cases. Figure 12 reveals the details of vertical wind differences 


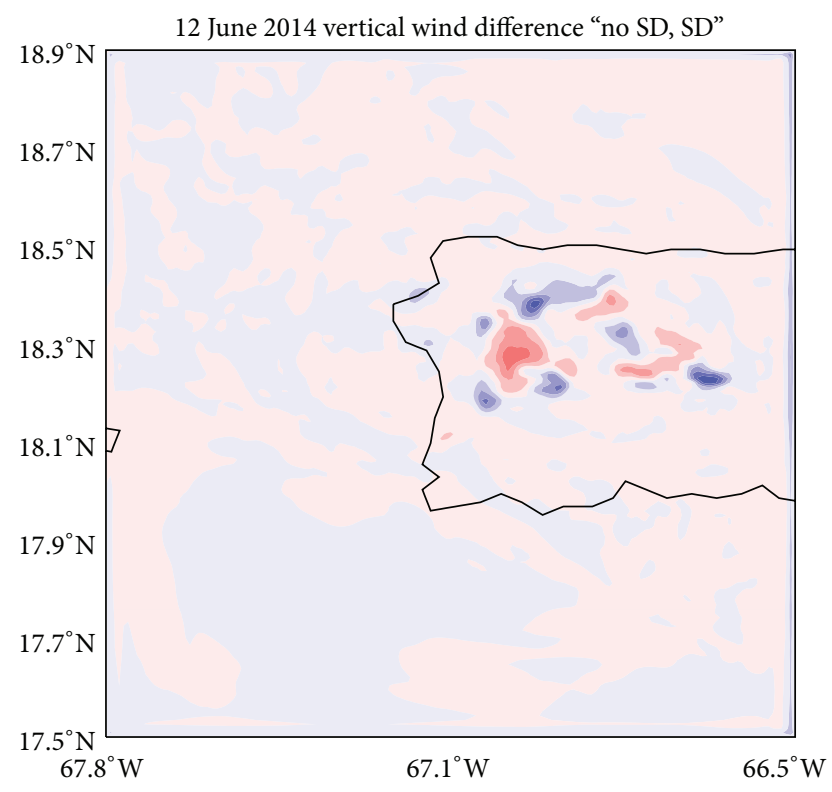

(a)

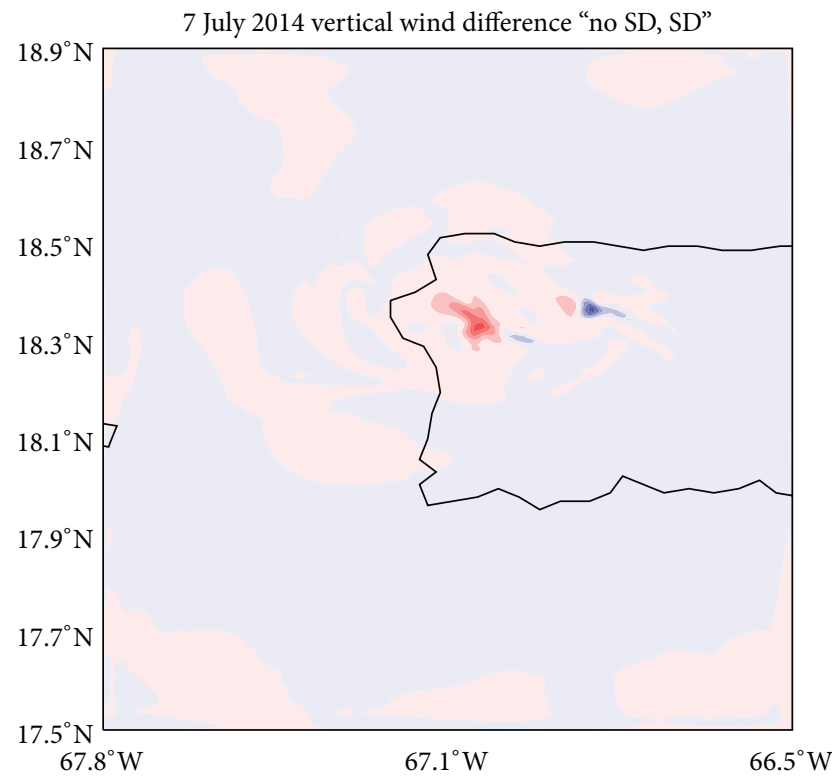

(c)

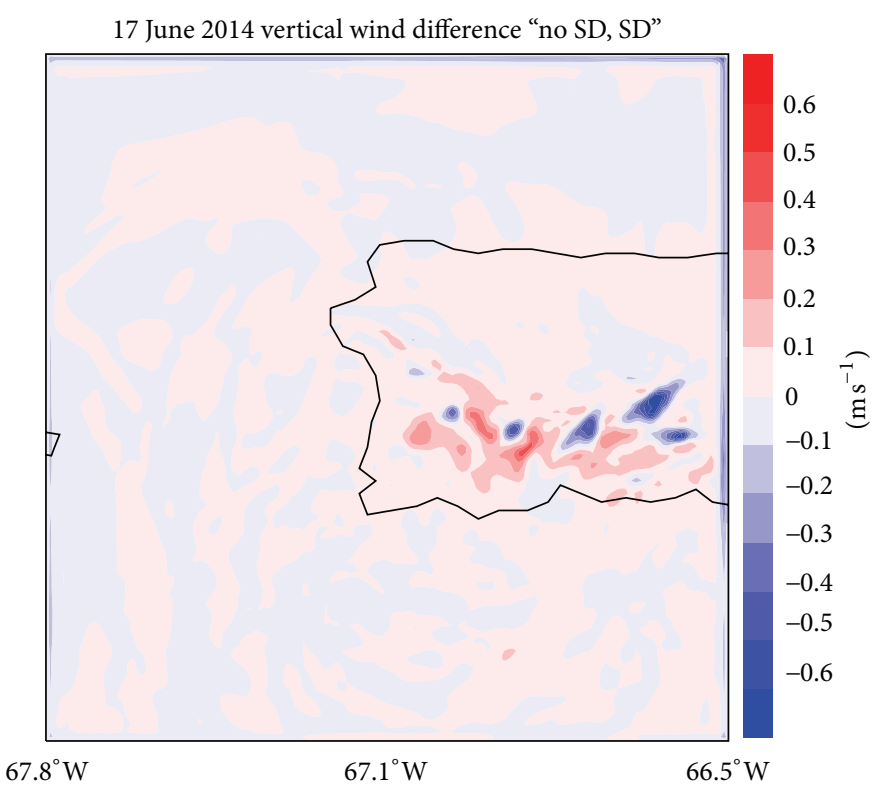

(b)

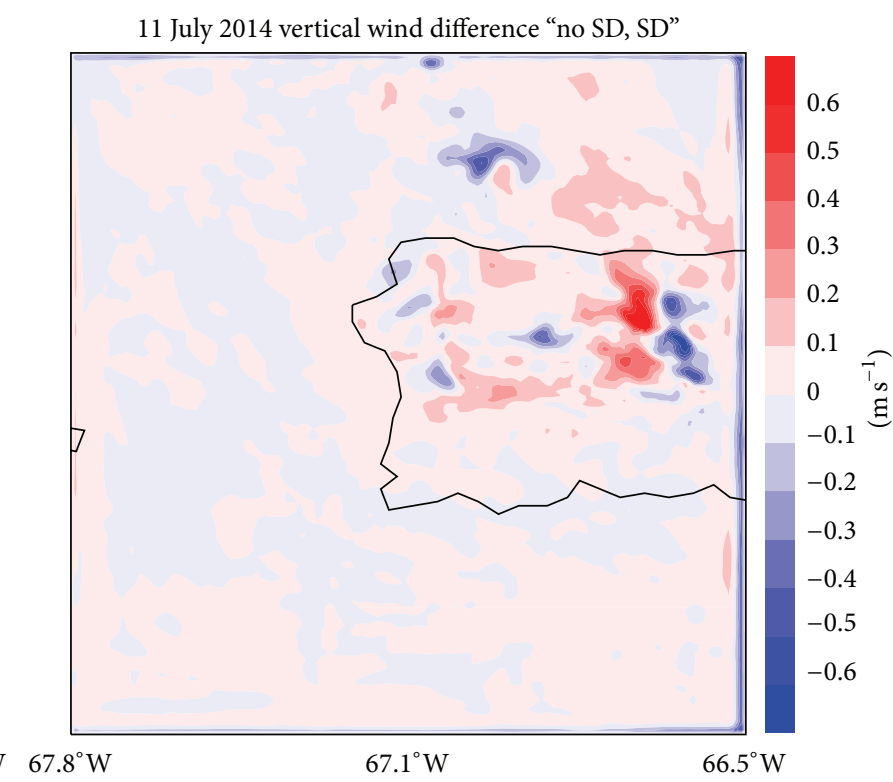

(d)

FIGURE 11: RAMS generated PBL (from the surface to $6000 \mathrm{~m}$ ) averaged vertical wind differences over the duration of the events for SD and no SD cases for 12 June 2014 (a), 17 June 2014 (b), 7 July 2014 (c), and 11 July 2014 (d).

between "SD" and "no SD" cases within the PBL for the case of Mayagüez, showing lower updrafts with the presence of SD by $1 \mathrm{~m} \mathrm{~s}^{-1}$ until approximately 1300 AST, when updrafts increase and are higher in the presence of SD than with no SD present by $3-5 \mathrm{~m} \mathrm{~s}^{-1}$. These convection patterns are attributed to early and late near-surface temperature differences and a rainfall suppression effect caused by increased dust concentrations. Although there is delay of rain here, this does not lead to intensified cold rainfall that is caused by the ascension of the cloud-aerosol system. This is in part attributed to the low solubility of the SD and also to warm temperatures in the PBL of the tropical atmosphere, which do not facilitate droplet freezing.

Figure 13 shows that the presence of the SD decreases moisture in the environment, resulting in a drier atmosphere such that clouds formed due to orographic effects and from coastal convergence do not have enough water vapor available to promote droplet growth amongst the multitudes of SD present. 12 June 2014 mixing ratio difference plots between "SD" and "no SD" indicate changes of up to approximately $-1.2 \mathrm{~g} \mathrm{~kg}^{-1}$ over the west, with small $+0.4 \mathrm{~g} \mathrm{~kg}^{-1}$ zones along the $18.21 \mathrm{~N}$ latitude. 17 June 2014 mixing ratio difference 


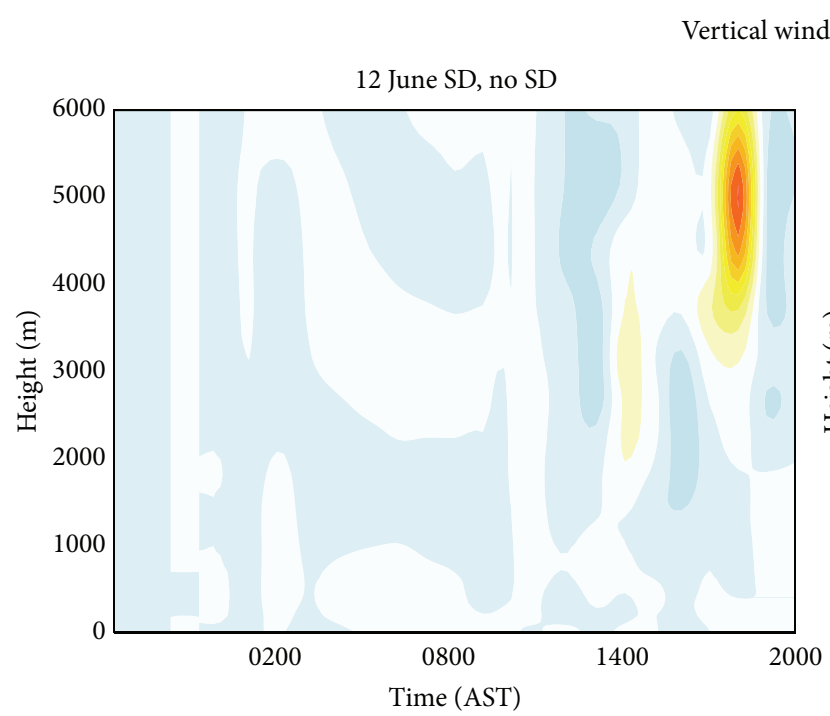

(a)

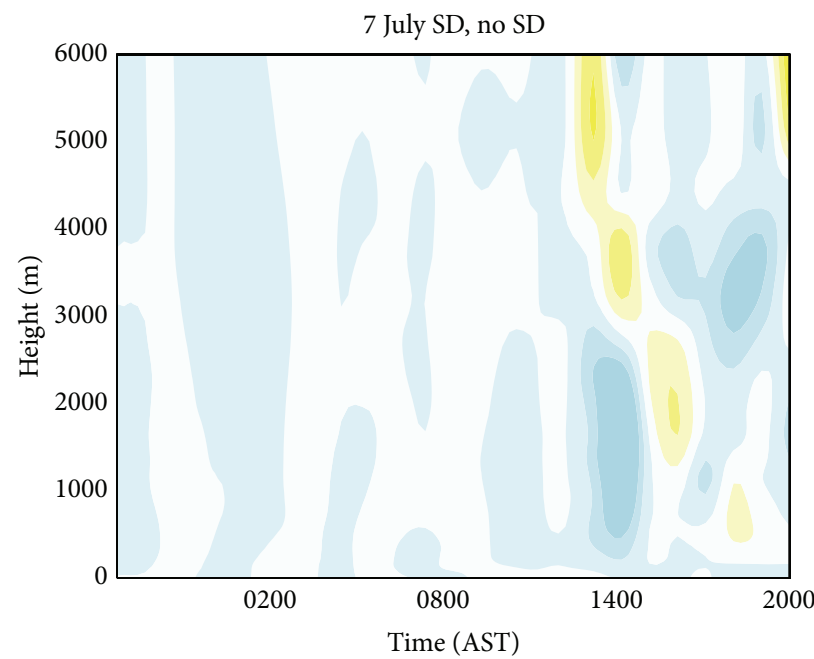

(c)

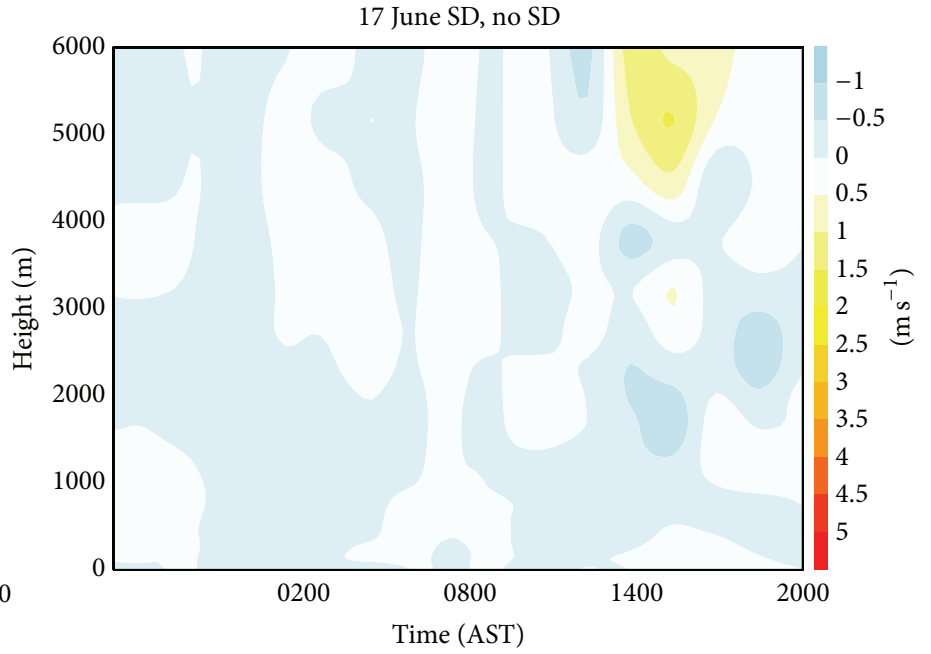

(b)

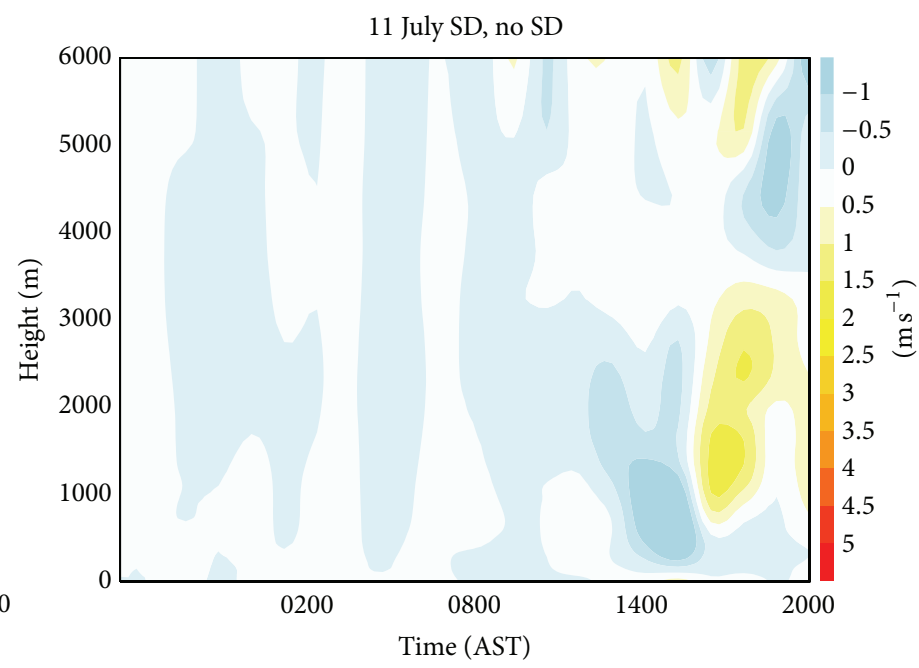

(d)

FIGURE 12: RAMS generated vertical wind (w) differences at Mayagüez between SD and no SD for 12 June 2014 (a), 17 June 2014 (b), 7 July 2014 (c), and 11 July 2014 (d).

plots between "SD" and "no SD" runs reveal moisture decreases between $18.21 \mathrm{~N}$ and the south coast $(17.9 \mathrm{~N})$ of up to $-1.2 \mathrm{~g} \mathrm{~kg}^{-1}$ and increases along the northern between $18.21 \mathrm{~N}$ and the north coast $(18.5 \mathrm{~N})$ of up to $+0.4 \mathrm{~g} \mathrm{~kg}^{-1}$. There is also an area at $65.7 \mathrm{~W}$ with increases of $1.2 \mathrm{~g} \mathrm{~kg}^{-1}$. Decreases of $-1 \mathrm{~g} \mathrm{~kg}^{-1}$ are shown for 7 July 2014 at the northwestern coast, with smaller decreases off of the western coast and inland. For 11 July 2014, the mixing ratio decrease ranges from -0.2 to $-1.4 \mathrm{~g} \mathrm{~kg}^{-1}$ from the southwest to the entire north coast. Increases of +0.2 are shown inland and off the northern and western coasts. Moisture decrease in aerosol rich environments may be attributed to the competing effects of CCN/GCCN for moisture availability, a process that has been documented for the Caribbean [24] and elsewhere [25].

\section{Conclusion}

We revisit the fundamental science questions pursued by this work: (1) To what degree do aerosols and SD impact convection and precipitation? (2) Can the presence of SD delay warm precipitation, resulting in more intense cold precipitation hours later?

The RAMS study provides information regarding the degree of aerosols/SD impact on convection and precipitation and whether the presence of SD delays warm precipitation resulting in more intense cold precipitation hours later. Here, there is no evidence of intense thunderstorms forming due to reduced rates of autoconversion, as other studies such as Carrió et al. [26] and Hosannah and González [27] have discussed. The authors attribute the lack of deep convection 


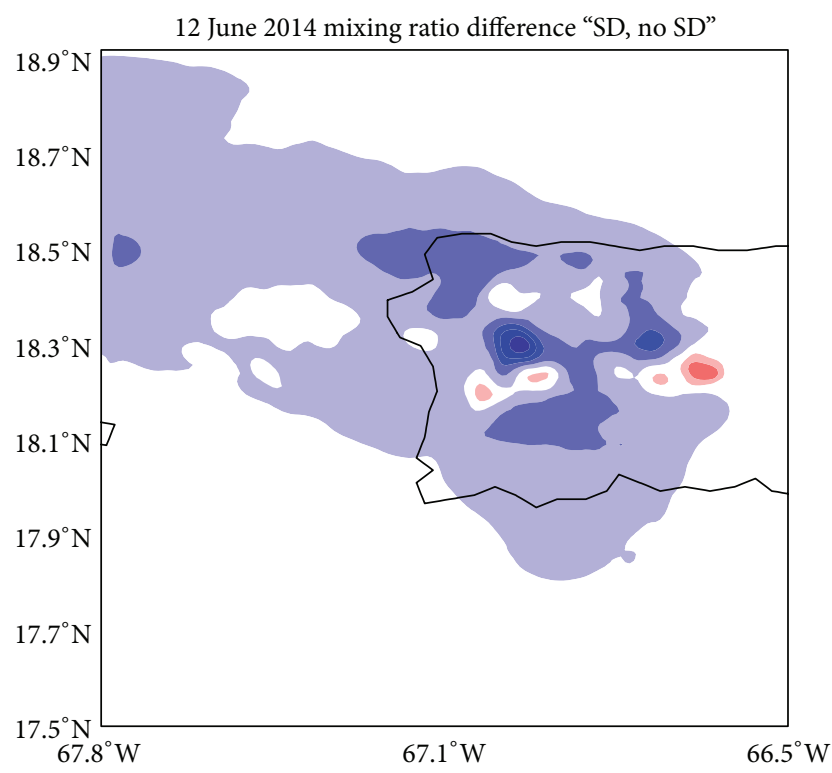

(a)

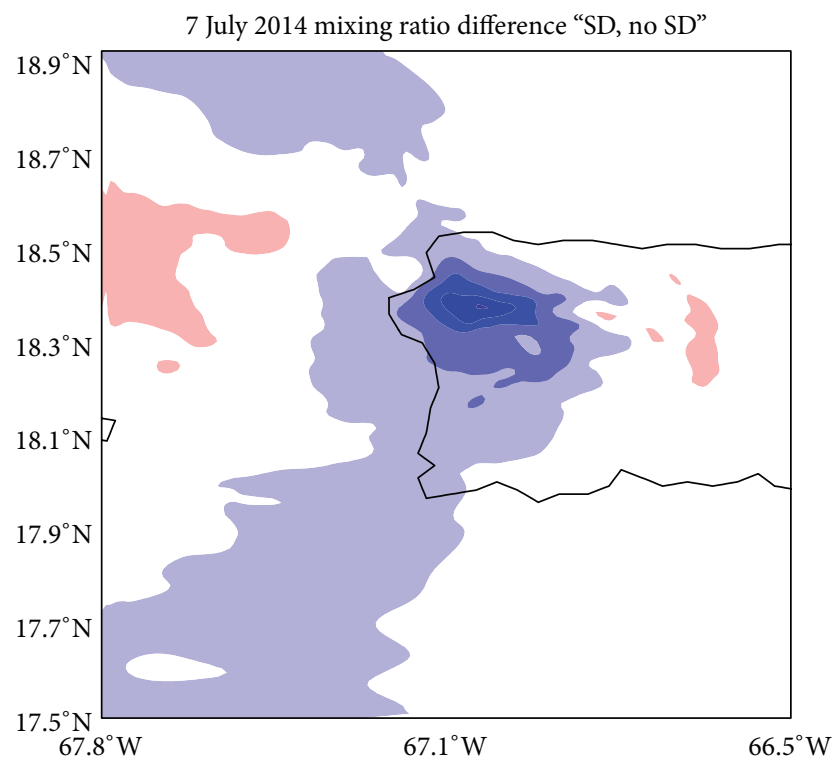

(c)

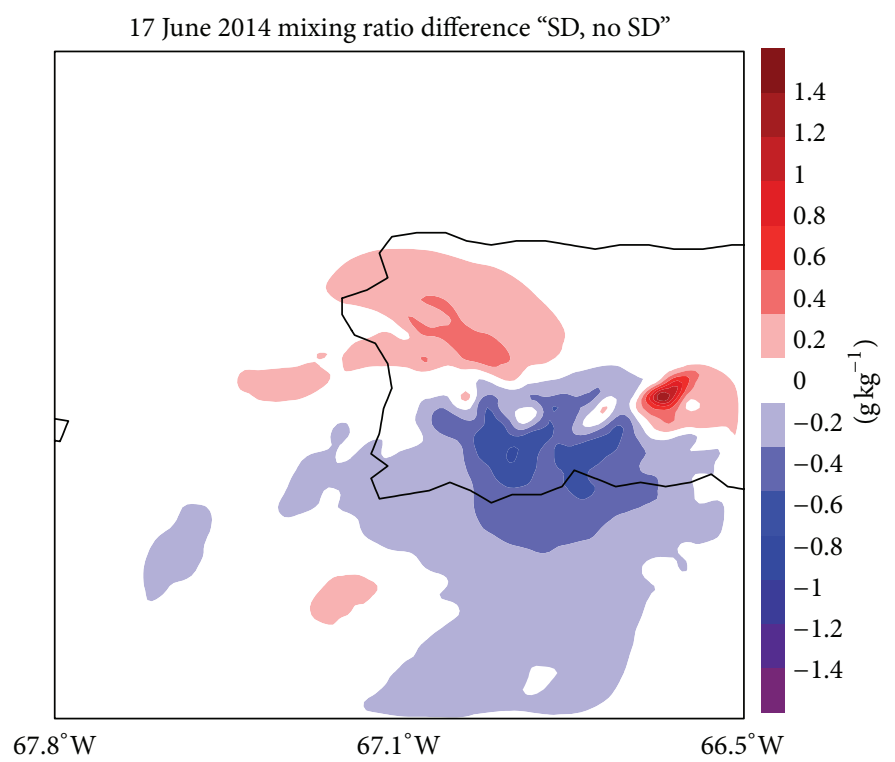

(b)

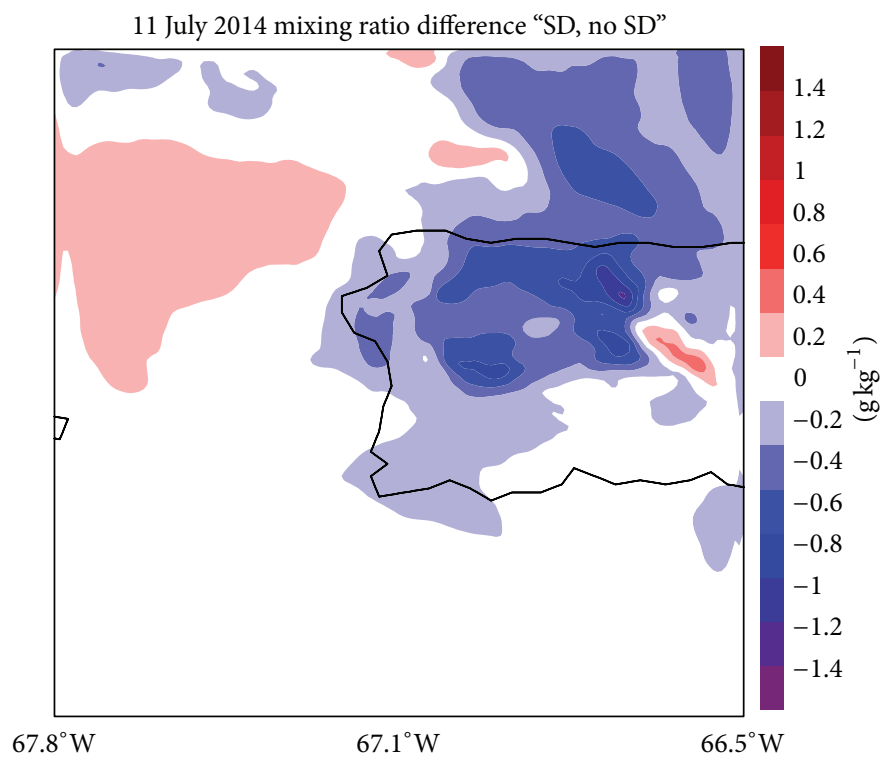

(d)

FIGURE 13: RAMS generated PBL averaged mixing ratio differences for 12 June 2014 (a), 17 June 2014 (b), 7 July 2014 (c), and 11 July 2014 (d).

to the fact that the clouds were warm and mainly of low level, which reduces the likelihood of colder ice particles forming and colliding/coalescing with the warmer droplets. Also, buoyancy is key to the development of deep convective storms, and CAPE during the measurement period was not high enough to produce severe deep moist convection. In order to test this hypothesis further, deep convective tropical precipitation events will need to be investigated.

In summary, this work encompasses an observational and modelling investigation into the impacts of dust on precipitation in coastal tropical environments. A campaign that included radiosonde launches, LIDAR, AERONET, and Ceilometer data was run for the western side of the island of Puerto Rico during the MSD season. Analysis of the data shows that (1) total accumulated daily rainfall for the period ranged from 0 to $140 \mathrm{~mm}$ with the heaviest precipitation concentrated on the western side of the island with clouds generally developing at a base between 1.5 and $3.5 \mathrm{~km}$, (2) dust was captured via LIDAR up to $4 \mathrm{~km}$ with heavy dust shielding clouds and producing less precipitation over Mayagüez than light dust by as much as 50\%, (3) sea breeze intensity reached $9 \mathrm{~ms}^{-1}$, impacting precipitation formation in afternoon storms when converging with easterlies, and (4) the west and east produced similar environmental temperature fields, while the west produced higher moisture than the east. 
Model results show the following. (1) Dust intrusion decreases the total accumulated precipitation and breaks large storm cells into smaller ones. (2) When dust is removed for a dry day, precipitation can occur. In the case of 7 July 2014, the "no SD" rainfall is attributed to convergence between the westerly sea breeze and easterly trade winds. (3) While there is evidence of rain being delayed due to the presence of dust, there is no increase in rainfall intensity or totals. This is likely due to the cloud levels being too low and too warm to produce ice particles. (4) Mixing ratio increases of up to $1.4 \mathrm{~g} \mathrm{~kg}^{-1}$ occur in the absence of SD, and (5) vertical wind increases of up to $0.8 \mathrm{~m} \mathrm{~s}^{-1}$ occur in the absence of SD, but not for all cases.

As the concepts surrounding this investigation are aimed towards building on previous works, there are some important aspects to consider. The modelling effort is supported with an observational analysis based on a 15-day campaign. More campaign data is required to conclusively elucidate how the presence (or lack of) of dust combines with SSTs, the NAHP, VWS, and other contributors to Caribbean precipitation modulation to modify rainfall on a seasonal basis. The results of this study show that data from in situ and remote sensors utilized together with modelling provides pertinent information about the impacts of SD on convection and precipitation in a coastal tropical environment. In addition, the inclusion of observed PSD data improves precipitation model results. While PSD ingested from point sources improved modelling results for the current work, grid based satellite derived PSD will be an optional improvement for future works.

\section{Conflict of Interests}

The authors declare that there is no conflict of interests regarding the publication of this paper.

\section{Acknowledgments}

This work was supported by the NOAA Office of Education Partnership Program Award no. NA11SEC4810004 and by the US Department of Education Earth Science and Environmental Sustainability (ESES) Graduate Initiative Award no. P031M105066. The authors would like to thank M. Santiago, H. Jimenez, J. Algarin, J. Castro, C. Cruz, J. Diaz, C. Gonzalez, R. Armstrong, V. Morris, and R. Rodriguez for their assistance in the work presented in this paper.

\section{References}

[1] M. R. Jury, "An intercomparison of observational, reanalysis, satellite, and coupled model data on mean rainfall in the Caribbean," Journal of Hydrometeorology, vol. 10, no. 2, pp. 413430, 2009.

[2] J. M. Prospero and P. J. Lamb, "African droughts and dust transport to the caribbean: climate change implications," Science, vol. 302, no. 5647, pp. 1024-1027, 2003.

[3] D. W. Gamble and S. Curtis, "Caribbean precipitation: review, model and prospect," Progress in Physical Geography, vol. 32, no. 3, pp. 265-276, 2008.
[4] M. E. Angeles, J. E. González, N. D. Ramírez-Beltrán, C. A. Tepley, and D. E. Comarazamy, "Origins of the Caribean rainfall bimodal behavior," Journal of Geophysical Research, vol. 115, Article ID D11106, 2010.

[5] I. Folkins and C. Braun, "Tropical rainfall and boundary layer moist entropy," Journal of Climate, vol. 16, no. 11, pp. 1807-1820, 2003.

[6] J. P. Dunion, "Rewriting the climatology of the tropical North atlantic and Caribbean Sea atmosphere," Journal of Climate, vol. 24, no. 3, pp. 893-908, 2011.

[7] D. Rosenfeld, Y. Rudich, and R. Lahav, "Desert dust suppressing precipitation: a possible desertification feedback loop," Proceedings of the National Academy of Sciences of the United States of America, vol. 98, no. 11, pp. 5975-5980, 2001.

[8] M. R. Jury and S. Chiao, "Leeside boundary layer confluence and afternoon Thunderstorms over Mayaguez, Puerto Rico," Journal of Applied Meteorology and Climatology, vol. 52, no. 2, pp. 439-454, 2013.

[9] R. Jaenicke and L. Schütz, "Comprehensive study of physical and chemical properties of the surface aerosols in the Cape Verde Islands region," Journal of Geophysical Research, vol. 83, no. 7, pp. 3585-3599, 1978.

[10] X. Li-Jones, H. B. Maring, and J. M. Prospero, "Effect of relative humidity on light scattering by mineral dust aerosol as measured in the marine boundary layer over the tropical Atlantic Ocean," Journal of Geophysical Research: Atmospheres, vol. 103, no. 23, Article ID 98JD01800, pp. 31113-31121, 1998.

[11] F. J. Dentener, G. R. Carmichael, Y. Zhang, J. Lelieveld, and P. J. Crutzen, "Role of mineral aerosol as a reactive surface in the global troposphere," Journal of Geophysical Research: Atmospheres, vol. 101, no. 17, pp. 22869-22889, 1996.

[12] K. A. Stofer, "Africa to Atlantic, dust to dust," in 2004 Earth Feature Story, NASA Goddard Space Flight Center, 2004.

[13] J. S. Reid, L. Douglas, L. Westphal et al., "Dust vertical distribution in the Caribbean during the Puerto Rico Dust experiment," Geophysical Research Letters, vol. 29, no. 7, pp. 55-1-55-4, 2002.

[14] W. M. Gray, "The mutual variation of wind, shear, and baroclinicity in the cumulus convective atmosphere of the hurricane," Monthly Weather Review, vol. 95, no. 2, pp. 55-73, 1967.

[15] T. F. Eck, B. N. Holben, J. S. Reid et al., "Fog and cloud-induced aerosol modification observed by the aerosol robotic network (AERONET)," Journal of Geophysical Research: Atmospheres, vol. 117, no. 7, Article ID D07206, 2012.

[16] O. Dubovik and M. D. King, "A flexible inversion algorithm for retrieval of aerosol optical properties from sun and sky radiance measurements," Journal of Geophysical Research: Atmospheres, vol. 105, no. 16, Article ID 2000JD900282, pp. 20673-20696, 2000.

[17] L. A. Otero, G. J. Fochesatto, P. R. Ristori et al., "Simple method to derive aerosol microphysical properties from AERONET multiwavelength direct solar measurements," Advances in Space Research, vol. 34, no. 10, pp. 2232-2235, 2004.

[18] J. Lenoble, Atmospheric Radiative Transfer, A. Deepak, 1993.

[19] S. M. Saleeby and S. C. van den Heever, "Developments in the CSU-RAMS aerosol model: emissions, nucleation, regeneration, deposition, and radiation," Journal of Applied Meteorology and Climatology, vol. 52, no. 12, pp. 2601-2622, 2013.

[20] F. Mesinger and Coauthors, "North American regional reanalysis," Bulletin of the American Meteorological Society, vol. 87, pp. 343-360, 2006. 
[21] T. M. Smith, R. W. Reynolds, T. C. Peterson, and J. Lawrimore, "Improvements to NOAA's historical merged land-ocean surface temperature analysis (1880-2006)," Journal of Climate, vol. 21, no. 10, pp. 2283-2296, 2008.

[22] Y. Mahrer and R. A. Pielke, "A numerical study of the airflow over irregular terrain," Beiträge zur Physik der Atmosphäre, vol. 50, pp. 98-113, 1977.

[23] E. Kalnay, M. Kanamitsu, R. Kistler et al., "The NCEP/NCAR 40-year reanalysis project," Bulletin of the American Meteorological Society, vol. 77, pp. 437-471, 1996.

[24] D. E. Comarazamy, J. E. Gonzalez, C. A. Tepley, S. Raizada, and R. V. R. Pandya, "Effects of atmospheric particle concentration on cloud mocrophysics over Arecibo," Journal of Geophysical Research: Atmospheres, vol. 111, no. 9, Article ID D09205, 2006.

[25] D. Rosenfeld, U. Lohmann, G. B. Raga et al., "Flood or drought: how do aerosols affect precipitation?” Science, vol. 321, no. 5894, pp. 1309-1313, 2008.

[26] G. G. Carrió, W. R. Cotton, and W. Y. Y. Cheng, "Urban growth and aerosol effects on convection over Houston. Part I: the August 2000 case," Atmospheric Research, vol. 96, no. 4, pp. 560$574,2010$.

[27] N. Hosannah and J. E. González, "Impacts of aerosol particle size distribution and land cover land use on precipitation in a coastal urban environment using a cloud-resolving Mesoscale model," Advances in Meteorology, vol. 2014, Article ID 904571, 17 pages, 2014. 

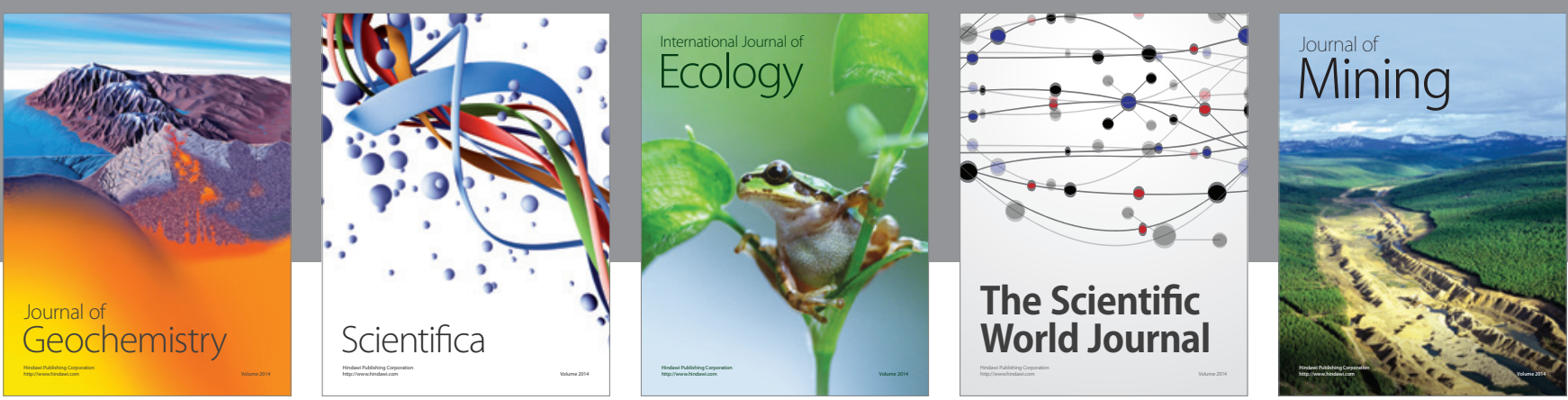

The Scientific World Journal
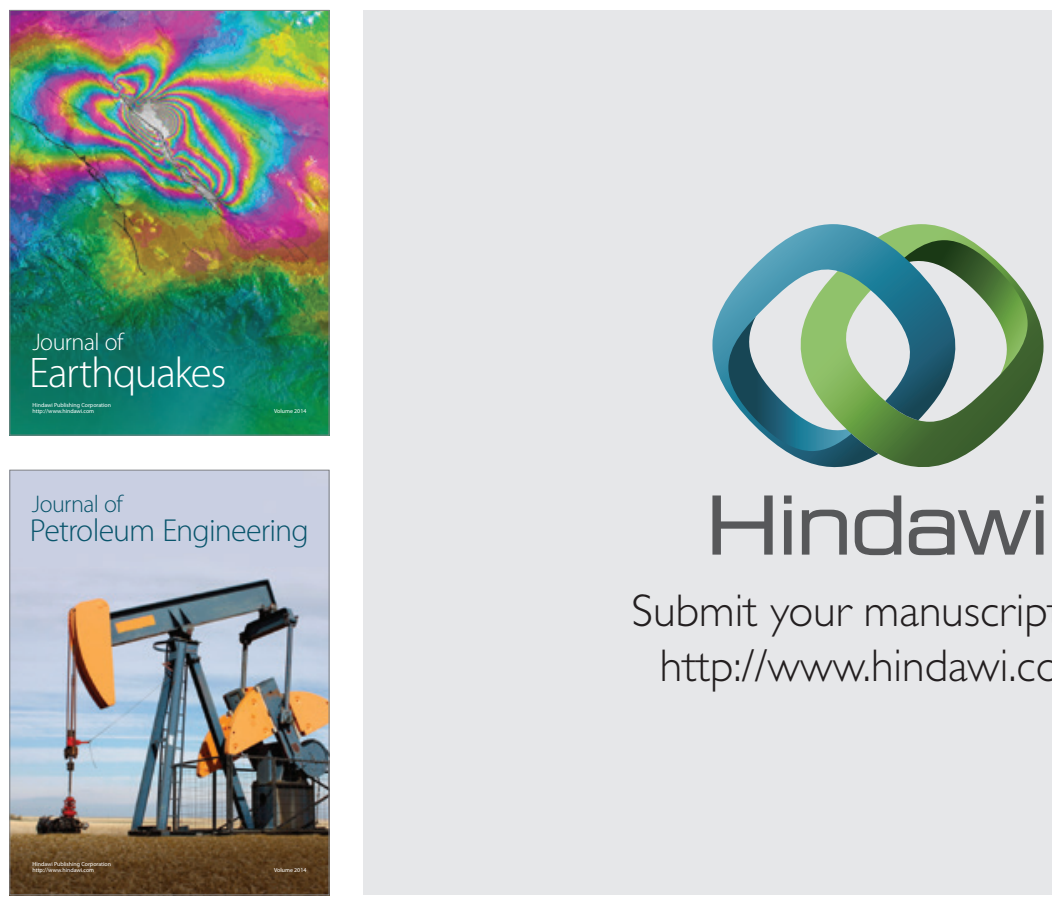

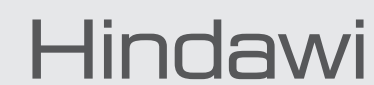

Submit your manuscripts at

http://www.hindawi.com
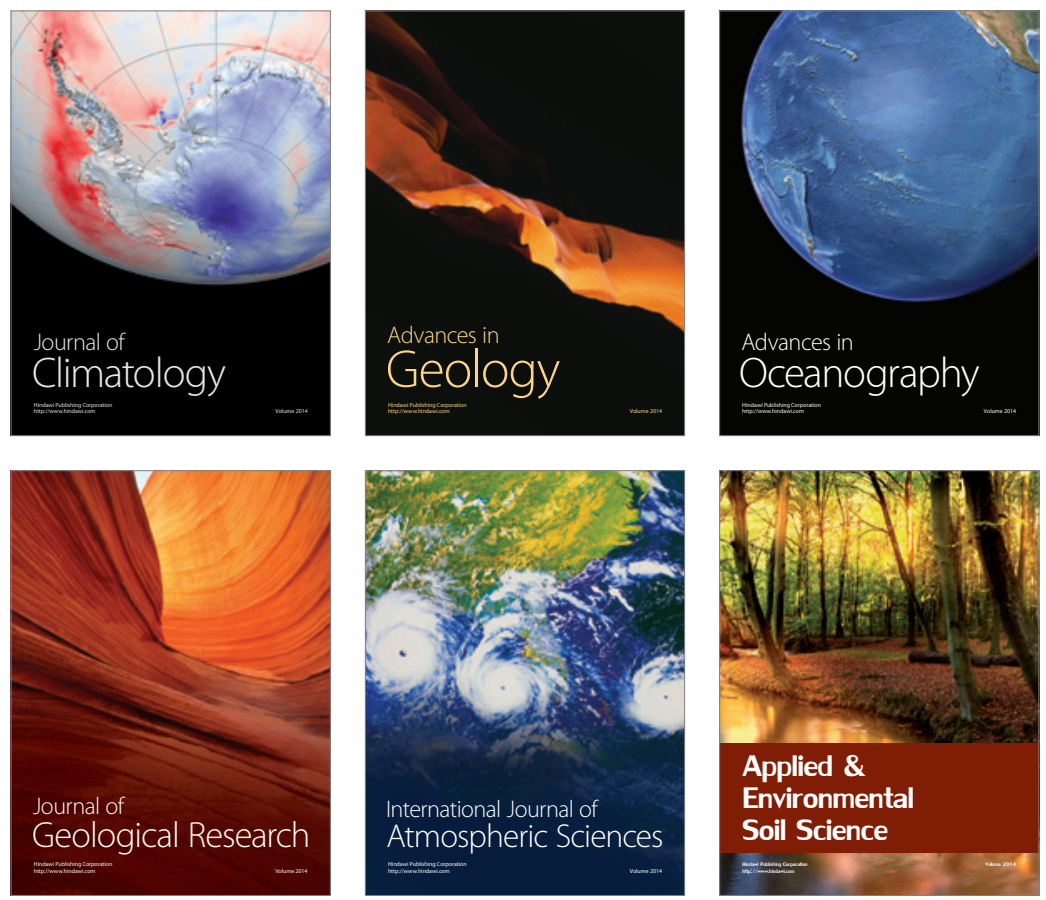
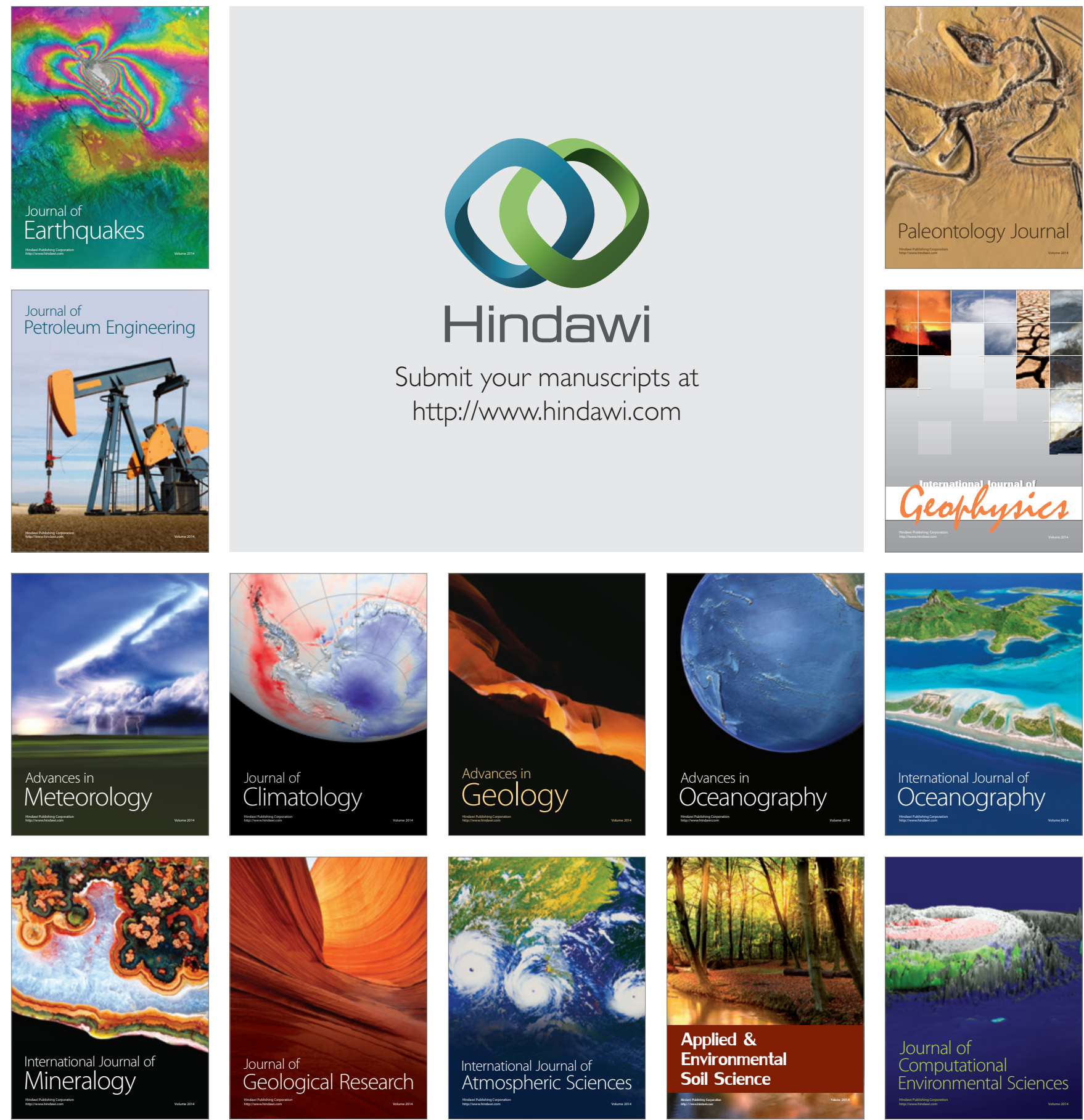